\title{
Bibliográfia
}

\section{A 2010-ben megjelent, jog- és államtudományi tárgyú könyvek annotált bibliográfiája - 3., befejező rész}

Folyóiratunkban rendszeresen jelenik meg az elmúlt időszak új, hazai szakkönyveiről készült, annotált bibliográfia. Az annotáció a könyv felhasználhatóságáról írott, rövid, tényszerü leírás, amely a bibliográfiai adatok mellett meghatározza a müfajt, illetve röviden körvonalazza a feldolgozott témát és a bemutatott eredményeket is. A folyóirat első két lapszámában terveztük a 2010-ben megjelent, önálló publikációk összegyűjtését. Vállalkozásunk elindítását követően azonban azt tapasztaltuk, hogy ez nem lehetséges, mivel az egy-egy évben megjelent szakkönyvek száma igen magas (2010-ben több mint 300 kiadvány jelent meg), illetve egy év teljes termése csak mintegy másfél-két év után válik elérhetővé a közkönyvtárakban, illetve az adatbázisokban. A 2010-ben megjelent munkák bemutatása így csak jelen számunkban válik teljessé.

Gyűjtőmunkánkat jelentős mértékben segítette a Debreceni Egyetem Egyetemi és Nemzeti Könyvtára, amely köteles könyvtárként a hazai kiadványok gyűjtését, feldolgozását, illetve részben - a mienkhez képest némileg eltérő szempontok szerint annotálását is elvégzi. Emellett kiadók honlapján, hírlevelekben, a szerzők publikációs listáiban és saját könyvespolcainkon is kutattunk. Gyakran a szerzők, kiadók által készített fülszövegeket, ajánlásokat is igyekeztünk fellelni és hasznosítani. Tisztában vagyunk azzal, hogy a feldolgozás szempontrendszere legjobb igyekezetünk ellenére is hiányos, illetve a sok szakterület és közremüködő okán egyenetlen. Örömmel veszünk és meg is szívlelünk ezért minden észrevételt, amely munkánkra vonatkozóan szerkesztőségünkhöz beérkezik.

A rovat belső szerkesztési elve szerint a kiadványokat témák (jogterületek) szerint csoportosítottuk. A leírások első, rövidebb része tartalmazza a könyvészeti adatokat (cím, szerző/szerkesztő, a kiadó neve, a kiadás helye és éve) az arra való utalással, hogy van-e a könyvben bibliográfia (irodalomjegyzék), illetve hogy a könyv milyen múfajba sorolható be. A terjedelmet oldalszámban adjuk meg, s közöljük a kötet azonosítására szolgáló ISBN-számot, illetve sorozatok esetében az ISSN-t. A második rész röviden leírja az alkotót, illetve alkotókat. Ezt követően (a változatlan utánnyomások kivételével) 6-12 sor terjedelemben számba vesszük a mű tárgyköreit, főbb eredményeit. Az eredmények értékelését azonban nem végezzük el. A gyűjteményes munkák esetében nem kerül sor valamennyi szerző név szerinti megemlítésére, s a tanulmányok számától, tematikai egymáshoz kapcsolódásától függ, hogy 
minden témát megnevezünk-e. A felsőoktatási tananyagok bemutatását a lehető legtömörebben végezzük el.

Az alább közölt annotációk elkészítésében a Debreceni Egyetem Állam- és Jogtudományi Karának munkatársai, illetve hallgatói müködtek közre: Árva Zsuzsanna (Á. Zs.) egyetemi docens, Balogh Judit (B. J.) egyetemi docens, Barta Attila (B. A.) egyetemi tanársegéd, Bodó László (B. L.) doktori ösztöndíjas, Dorka Dóra (D. $D$.) doktori ösztöndíjas, Fazekas Flóra (F. F.) egyetemi adjunktus, Fodor László egyetemi tanár, Lukács Nikolett (L. N.) doktori ösztöndíjas, Petö Alexandra (P. A.) doktori ösztöndíjas, Szabó Zsuzsanna (Sz. Zs.) egyetemi tanársegéd, Tóth Andrea Noémi (T. A. N.) doktori ösztöndíjas, Török Éva (T. É.) predoktori ösztöndíjas, Tarkó Izabel Ágnes (T. I. Á.) joghallgató.

\section{ALKOTMÁNYJOG, EMBERI JOGOK, JOGELMÉLET}

- Az emberi jogok alapjai

BAYER Judit - Kállal Gábor

L'Harmattan - Zsigmond Király Főiskola, Budapest, 2010.

(Sorozat: Társadalomtudomány, ISSN 1787-8918)

Föiskolai jegyzet. Terjedelem: 310. Bibliográfia nincs. ISBN 9789632363202.

- A szerzők főiskolai oktatók. Tankönyvüket elsősorban azoknak a hallgatóknak szánják, akiknek nem a jog az alapszakjuk. Ezért igyekeznek az emberi jogokkal kapcsolatos gyakorlati ismereteket közérthető nyelven összefoglalni, ugyanakkor az emberi jogok elméleti, logikai hátterét, alkalmazásuk módszereit is bemutatni.

- Természetjog és emberi jogok

FRIVALDSZKY János

Budapest, PPKE JÁK, 2010.

Kézikönyv. Terjedelem: 165. Bibliográfia: 159-164. ISBN 9789633080016.

- A szerző egyetemi oktató. Kiindulópontja az, hogy napjainkban számos, az emberi jogokat alapvetően érintő jogintézmény (például az abortusz, az azonos nemüek házassága) melletti törekvés az emberi jogok eredeti tartalmával ellentétes felfogásból ered, amellyel szemben helyesen az emberi természetből logikai szükségszerüségként fakadó jogokkal kell érvelni. Könyve ennek jegyében tizenkét részben tekinti át a természetjog és az emberi jogok kapcsolatát Jacques Maritaintől a metafizikai és deduktív módszerekig. (L. N.)

- Jog-Irodalom

H. SZILÁGYI István

SZTE ÁJTK Összehasonlító Jogi Intézet, Szeged, 2010.

Tanulmánykötet. Terjedelem: 177. Bibliográfia a lábjegyzetekben. ISBN 978963 3060216.

- A kötetben szereplő öt nagyobb tanulmány a szerző habilitációs eljárásának alapjául szolgáló ,jog és irodalom” tárgykörét tekinti át tematikusan. Az általa vizsgált, Amerikában az 1970-es években elindult és azóta több ágra bomlott, komoly jog- 
filozófiai megalapozottsággal művelt, frekventált jogelméleti irányzat itthon kevéssé ismert. A szerző a jogi antropológia területéröl érkezve tesz kísérletet a jog és irodalom (Law and Literature), a jog az irodalomban (Law in Literature) és a jog mint irodalom (Law as Literature) hazai megismertetésére. A jogbölcselők körében a témát kísérő kétségek eloszlatása, illetve a tárgykör jogelméleti perspektíváinak felvázolása érdekében olyan neves szerzőkre is támaszkodik, mint Richard Posner, Peter Brooks vagy Ronald Dworkin. (B. J.)

- Föderalizmus és nemzeti kérdés. Az etnoföderalizmus tapasztalatai Közép- és Kelet-Európában

JuHÁsz József

Gondolat, Budapest, 2010.

Kézikönyv/Monográfia. Terjedelem: 221. Bibliográfia: 217-221. ISBN 978963693 2350.

- A szerző egyetemi oktató. Jelen kötete a világban létező föderális rendszerek összehasonlító vizsgálatára vállalkozik, külön hangsúlyt fektetve a közép- és keleteurópai példákra (Szovjetunió, Jugoszlávia, Csehszlovákia és a posztszocialista föderációk). Az első fejezetek a föderalizmus általános jellemzőit és a nyugati etnoföderális államok sajátosságait vizsgálják, majd a közép- és kelet-európai etnoföderalizmus történetének bemutatása, a térség többnemzetiségű szövetségi államainak összehasonlító elemzése következik. A kötet megállapításai az európai integráció jelenlegi és jövőbeni helyzetének elemzéséhez is segítséget nyújtanak. A kötet végén összehasonlító táblázatokat és térképeket találunk. (F. F.)

- A képviselök jogállása és javadalmazása

Karsai József (szerk.)

4., átdolgozott és bővített kiadás. Országgyülés Hivatala, Budapest, 2010.

Jogszabálygyüjtemény. Terjedelem: 198. Bibliográfia: 190-198. ISBN 9789639848 375.

- A szerző volt országgyülési képviselö. A kiadvánnyal a 2010-ben alakult Országgyűlés képviselőinek munkáját kívánja segíteni. A kötet tartalmazza az alkotmány képviselői jogállással kapcsolatos rendelkezéseit és a 2010-ben még hatályos, 1990-es törvényeket a képviselők jogállásáról, illetve javadalmazásáról. A jogszabályszövegeket a Házszabály rendelkezései, országgyülési bizottsági és adatvédelmi biztosi állásfoglalások, alkotmánybírósági és legfelsőbb bírósági határozatok egészítik ki. A kötetet a témakörhöz illeszkedő statisztikák, összeállítások, táblázatok zárják. (F. F.)

\section{- Jogszociológia}

MACZONKAI Mihály

A 2005-ös kiadás változatlan utánnyomása. Dialóg Campus, Budapest-Pécs, 2010. (Sorozat: Institutiones Juris, ISSN 1218-9375; Studia Sociologica, 1786-4887; Dialóg Campus Tankönyvek, ISSN 1418-1274)

Tankönyv. Terjedelem: 192. Bibliográfia: 184-192. ISBN 978963954233 4. (L. N.) 
- Josef K. nyomában - jogról és irodalomról

NAGY Tamás

Attractor, Máriabesnyő-Gödöllő, 2010.

Monográfia. Terjedelem: 266. Bibliográfia: 245-266. ISBN 9789639857568.

- A szerző egyetemi oktató. A hazánkban úttörőnek számító munkája a jog és az irodalom kapcsolatát vizsgálja: mennyiben jelenik meg az adott korszak jogászi világa az irodalmi alkotásokban (többek között az angol és amerikai irodalom ismert írói, például Henry James vagy Upton Sinclair múveiben), illetve a jogi szövegek mennyiben képezik az irodalom tárgyát. A szerző angolszász minták alapján vizsgálja ezt a Magyarországon kevéssé ismert interdiszciplináris tudományterületet. (L. N.)

- Emberi jogok a Katolikus Egyház életében és jogában

Orosz András Lóránt OFM (szerk.)

L'Harmattan - Sapientia Szerzetesi Hittudományi Főiskola, Budapest, 2010.

(Sorozat: Sapientia luris, ISSN 2061-7879; 1.)

Tanulmánykötet. Terjedelem: 204. Bibliográfia a lábjegyzetekben. ISBN 978963 2362663.

- A szerzők egyetemi, főiskolai oktatók, egyházjogászok. Tanulmányaik az emberi jogok jelentőségét és megjelenését vizsgálják a katolikus egyházjogban. A kötet célja annak bemutatása, hogy az egyházjogban és egyházi filozófiában is léteznek az emberi jogokat érintő kérdések, ám ezek (például az emberi élet védelme, a privátszféra vagy a vallásszabadság) mást jelentenek a világi jogrendben rögzítettekhez képest. A tanulmányok az ókori, természetjogi és középkori gondolkodástól John Rawls keresztény etikai gondolkodásán keresztül napjaink katolikus egyházjogi nézeteiig tekintik át az emberi jogok és a katolikus egyházi ideológia viszonyát. Az egyház néhány belső életét érintő kérdés, például a papnevelés, a szerzetesi élet vagy a szociális tanítások is helyet kaptak a kötetben. (L. N.)

\section{- Autentikus jogelmélet}

Pokol Béla

Dialóg Campus, Budapest-Pécs, 2010.

(Sorozat: Institutiones Juris, ISSN 1218-9375; Dialóg Campus szakkönyvek, ISSN 1417-7986)

Kézikönyv. Terjedelem: 207. Bibliográfia az egyes fejezetek végén. ISBN 978963 9950221.

- A szerző jogász, politológus, egyetemi oktató. Jelen kötetének célja szakítani azzal a múlt században meggyökeresedett és ma is élő jogelmélet-felfogással, amely a jogtörténet és a tételes jogtudományok kutatásától elszakadva „felülröl” figyeli meg és elemzi a jogot. Ezért kötetében az általános jogelmélet hagyományos kérdéseit a jogtörténet, a magánjog és a büntetőjog elméleti vonalaival együtt tárgyalja. A könyv hét fejezete a jogelmélet diszciplináris önreflexiójától indulva többek között Habermas, Hart és Jhering elméletein keresztül, a római kortól napjainkig kialakuló mai jogrendszerekig vizsgálja a modern jog történetét és jogelméletét. Az utolsó két fejezet a büntetőjog és a magánjog elméleteivel foglalkozik. (L. N.) 
- Morálelméleti vizsgálódások. A közmorál elméleti eltüntetésének kritikája

Pokol Béla

Kairosz, Budapest, 2010.

Kézikönyv/Esszé. Terjedelem: 160. Bibliográfia: 159-160. és az egyes fejezetek végén. ISBN 9789636623647.

- A szerző jogász, politológus, egyetemi oktató; e kötetében morálelméleti elemzéseket ad közre. Vizsgálódásai tudományos célt követnek, emellett azonban nem titkolt célja a közéletben véleménye szerint zavarosan használt morál, erkölcs, közerkölcs, közmorál fogalmak tisztázása a közéleti szereplők számára is. Az első, fogalommagyarázó fejezet után elsősorban Hartmann, Rawls, Habermas és Hart morálelméletével és azok kritikájával foglalkozik részletesen. (F. F.)

- Az állam és jog alapvető értékei. Széchenyi István Egyetem Állam- és Jogtudományi Doktori Iskola konferenciája I-II.

Smuk Péter (szerk.)

Széchenyi István Egyetem Állam- és Jogtudományi Doktori Iskola, Győr, 2010.

Konferenciakötet. Terjedelem: 408 (I. kötet), 196 (II. kötet). Bibliográfia a lábjegyzetekben. ISBN 9789637175602.

- A szerzők PhD-hallgatók. A kétkötetes gyűjtemény a 2010 végén a győri Állam- és Jogtudományi Doktori Iskola által rendezett konferencián elhangzott előadások szerkesztett változatait tartalmazza. A kilenc magyar és három külföldi doktori iskola hallgatói hét szekcióban (alkotmányjog és politikatudomány, büntetőjog, közigazgatási jog, magánjog, jogelmélet, európai jog, nemzetközi jog) magyar, illetve angol nyelven mutattak be dolgozatokat. A kötet ekként képet ad a magyarországi (sőt határon túli) jogászdoktori képzés teljes spektrumának eredményeiről. (F. F.)

- John Austin és a klasszikus analitikus iskola jogelmélete

TAKács Péter

ELTE ÁJK, Budapest, 2010.

(Sorozat: Sisyphus, ISSN 2061-6724; Bibliotheca luridica, ISSN 1586-8265; 41.) Egyetemi előadás-gyűjtemény. Terjedelem: 84. Bibliográfia: 78-83. ISBN 978963 2841427.

- A szerző egyetemi oktató. Jelen kötete a 2005 és 2010 között tartott egyetemi előadásainak szerkesztett, kibővített és szemléltető irodalmi, jogi idézetekkel kiegészített anyaga. A könyv három része a jogi pozitivizmussal, annak kialakulásával, elméletével és fogalmával, Jeremy Bentham és John Austin jogelméletével, valamint a klasszikus analitikus iskola tanaival foglalkozik. Az egyes részek tartalmazzák az iskolák kialakulásának körülményeit, jeles képviselőinek bemutatását, valamint jogelméleti álláspontjaikat is. A könyv képekkel és ábrákkal gazdagon illusztrált, amelyek a könnyebb megértést szolgálják. A kötet végén részletes névmutató, bibliográfia és számos jegyzet található. (L. N.) 
- Címszavak alkotmányjogi kislexikonhoz

Tóth Károly

Magánkiadás, Szeged, 2010.

Lexikon. Terjedelem: 341. Bibliográfia: a jegyzetekben. ISBN 9789630692809.

- A szerző egyetemi oktató. A kötetben olyan alkotmányjogi fogalmak értelmét, magyarázatát igyekszik megadni, amelyeket az egyetemi hallgatók és a közéleti szereplők is gyakran félreérthetően, hibásan használnak (pl. törvényhozás-törvénykezés, törvénytervezet-törvényjavaslat, eskü-fogadalom elhatárolása). A szerző a magyar jogban nem létező fogalmakat is tárgyal (pl. főbíró, minisztériumi rendelet), hogy ezzel is ösztönözzön használatuk mellőzésére. A változatos tárgyú függelék jogszabályszövegeket, illetve áttekintő táblázatokat tartalmaz (pl. Magyarország államfői, miniszterelnökei, latin szavak és kifejezések jegyzéke, ismert alkotmányjogászok születési és halálozási éve stb.). (F. F.)

\section{BÜNÜGYI TUDOMÁNYOK}

- Bevezetés a büntető anyagi jogba

AmBrus István - JuHÁsz Zsuzsanna - VIDA Mihály

Pólay Elemér Alapítvány, Szeged, 2010.

(Sorozat: A Pólay Elemér Alapítvány Tansegédletei, ISSN 1786-3554)

Tankönyv. Terjedelem: 378. Bibliográfia: 377-378. ISBN nincs.

- A szerzők egyetemi oktatók. Jegyzetük elsősorban a jogi asszisztens felsőfokú szakképzésben résztvevők számára készült, s célja a büntető anyagi jog ismeretanyagának e célközönség számára történő feldolgozása. A kötet a büntető törvénykönyv felosztásához igazodva általános, illetve különös részre tagolódik. Az általános rész a büntetőjog-tudomány, az alapelvek, a büntető jogszabálytan, a büncselekmény tana, illetőleg a büntetőjogi jogkövetkezmények tana és a fiatalkorúak büntetőjoga témaköreit dolgozza fel. A különös részi fejezetek a Btk. fejezeteihez igazodva tárgyalják a bűncselekményeket. (T. A. N.)

\section{- Büntetőjog I. Általános rész}

Balogh Ágnes - KöHALmı László

3., átdolgozott kiadás. Dialóg Campus, Budapest-Pécs, 2010.

(Sorozat: Dialóg Campus Szakkönyvek, ISSN 1417-7986; Jogi Szakvizsga Segédkönyvek, ISSN 1587-6659)

Tankönyv. Terjedelem: 317. Bibliográfia: 317. ISBN 9789639310599.

- A szerzők egyetemi oktatók. Könyvük elsősorban a jogi szakvizsgára történő felkészülést hivatott elösegíteni, célja a felkészülök számára egységes képet adni a büntetőjog elméletéről és gyakorlatáról. Ezt szem előtt tartva a kötet tartalma a minisztériumi szakvizsga kérdéssorhoz igazodik, s az egyes eltérő dogmatikai álláspontok minél teljesebb bemutatása érdekében a hazai büntetőjogi tankönyvek, szakkönyvek és kommentárok anyagát használja fel. A szakvizsga követelményeire tekintettel fokozott figyelmet fordít a bírói gyakorlat és a jogalkalmazás során felmerülő problémák ismertetésére. A kötetben kurzívval szedve találhatók a meg- 
jelenés után hatályba lépett jogszabályváltozások. A kötet anyagának elsajátítását könnyíti az egyes fejezetek elején a kapcsolódó jogszabályhelyek és jogegységi határozatok megjelölése. (T. A. N.)

\section{- Magyar büntetöjog. Általános Rész} BLAskó Béla

4., átdolgozott és bővített kiadás. Rejtjel, Budapest-Debrecen, 2010. Tankönyv. Terjedelem: 679. Bibliográfia: 673-679. ISBN 9789637255687.

- A szerző egyetemi oktató. Tankönyve tizenkét jól tagolt fejezetben tekinti át a büntetőjogi általános részi tanok klasszikus témaköreit (történeti vázlat, jogszabálytan, bủncselekménytan, büntetőjogi felelősségre vonás akadályai, bủncselekmény stádiumai, elkövetök, jogkövetkezmények, fiatalkorúakra és katonákra vonatkozó rendelkezések stb.). A kötet mellékletében tizennyolc áttekintő táblázatot tartalmaz (pl. az általános törvényi tényállás rendszeréröl, tárgyáról, szubjektív elemeiről, a büntethetőségi akadályokról, a büntethetőséget kizáró okokról, a tévedés fajtáiról). Emellett az áttekintést könnyítik a számozott bekezdések, félkövér kiemelések és az eseti döntések eltérő betümérete. (T. A. N.)

\section{- Büntetőjog. Általános rész}

Busch Béla (szerk.)

5., hatályosított kiadás. HVG-ORAC, Budapest, 2010.

Tankönyv. Terjedelem: 576. Bibliográfia: 563-567. ISBN 9789632580746.

- A kötet szerzői egyetemi oktatók, jogtudósok. A tankönyv a korábbi kiadásokhoz hasonlóan bemutatja az európai jogi gondolkodás és a magyar büntetőjog tudománytörténeti kapcsolatát, a jogállami büntetőjog kifejlődését és elveit, valamint a büntetőjog alapvető intézményeinek, így a büncselekmény tanának és a büntetés tanának filozófiáját és dogmatikáját. Mindemellett kitekintést ad a nemzetközi és az európai, illetve a hazai büntetőjog intézményrendszereinek kapcsolatára is. A kötetben a büntetőjog elméletének bemutatásához szervesen kapcsolódik a tételes joganyag és a joggyakorlat ismertetése. A megértést több fejezetben áttekintő táblázatok és magyarázó ábrák segítik. (T. A. N.)

\section{- A büntető ítélet igazságtartalma}

Erdei Árpád (szerk.)

Magyar Közlöny Lap- és Könyvkiadó, Budapest, 2010.

Konferenciakötet. Terjedelem: 174. Bibliográfia a lábjegyzetekben. ISBN 978963 9722897.

- A szerzők egyetemi oktatók, gyakorló jogászok. A kötet a debreceni jogi karon 2010 tavaszán azonos címmel rendezett konferencia előadásainak szerkesztett változatát tartalmazza. A tanulmányok a büntetőeljárás egyik központi kérdésének, az igazság megállapításának témakörét járják körül, hol általános jelleggel („mi az igazság?”, „a vád igazsága”, a kölcsönös elismerés elve, prekoncepciók és elöítéletek), hol egyes részkérdések (a súlyosítási tilalom szerepe, részbizonyítás a másodfokú eljárásban, a szembesítés módszere, a tárgyalásról lemondás, a sztereotípiák szerepe) bemutatásával. (T. A. N.) 
- A kábítószer-abúzus orvosi, jogi és társadalmi vonatkozásai

Fürst Zsuzsanna - Wenger Tibor (szerk.)

Medicina, Budapest, 2010.

Kézikönyv. Terjedelem: 282. Bibliográfia: 267-274. ISBN 9789632262741.

- A szerzők klinikai orvosok, pszichológusok, jogászok, szociológusok. A kötet a kábítószerekkel kapcsolatos komplex, egyre fiatalabb korosztályokat is érintő problémák feltárásában nyújt segítséget. A különböző kábítószerek élettani hatásain túl a gyakorlati orvosi teendőket is ismerteti, összefoglalja a kábítószer-túladagolás, az intoxikáció, valamint az elvonás legfőbb klinikai tüneteit, a detoxikálás, a tartós rehabilitáció terápiás/pszichoterápiás lehetőségeit. A kötet utolsó fejezete kifejezetten a témakör büntetőjogi kérdéseivel (mint a nemzetközi és hazai szabályozás áttekintése, az egyes elkövetési magatartások értelmezése, a bírói gyakorlat, az iskolai drogfogyasztás jogi vonatkozásai) foglalkozik. (T. A. N.)

- Magyar büntetőjog. Általános részi ismeretek

Görgényi llona (szerk.)

Bíbor Kiadó, Miskolc, 2010.

Főiskolai jegyzet. Terjedelem: 314. Bibliográfia nincs. ISBN 9789639988019.

- A szerzők egyetemi oktatók. Tankönyvük elsősorban a hároméves igazságügyi igazgatási képzésben részt vevők számára készült, így a hagyományos büntetőjogi tankönyvekkel összehasonlítva szükebb tartalommal rendelkezik. A kötet négy fő részre tagolódik: a büntetőjog és a bünügyi tudományok; jogszabálytan; büncselekménytan; valamint a büntetőjogi jogkövetkezmények tana. A tananyag elsajátítását táblázatok, félkövér és dőlt kiemelések, felsorolások segítik. (T. A. N.)

\section{- Büntető eljárásjog}

HERKE Csongor

Dialóg Campus, Budapest-Pécs, 2010.

(Sorozat: Dialóg Campus Szakkönyvek, ISSN 1417-7986; Jogi Szakvizsga Segédkönyvek, ISSN 1587-6659)

Tankönyv. Terjedelem: 479. Bibliográfia nincs. ISBN 9789639542365.

- A szerző egyetemi oktató. Kötete kifejezetten a büntető eljárásjogi szakvizsgára készülőknek kíván segítséget nyújtani. Tartalmában a jogi szakvizsgatételsorhoz igazodik, így nem az elméletre helyezi a hangsúlyt, hanem a Be. szabályait rendszerezi, s kiegészíti azt a kapcsolódó alkotmánybírósági határozatokkal, a Legfelsőbb Bíróság véleményeivel, eseti döntéseivel, jogegységi határozataival. Az önellenőrzést segítik az egyes fejezetek végén található alapvető és kiegészítő kérdések, melyekhez megoldó kulcs is tartozik. A kötet elején listába szedve találjuk a vonatkozó jogszabályokat és bírósági döntéseket, a kötet végén pedig iratminták sokasága segíti a büntetőeljárás gyakorlatának elsajátítását. (T. A. N.)

- Miként vélekedünk a jogról?

KeLEMEN László

Line Design, Budapest, 2010.

Monográfia. Terjedelem: 215. Bibliográfia: 207-215. ISBN 9789638818133. 
- A szerző ügyvéd és pszichológus. Munkája a jog és a pszichológia határterületén mozog, tárgya a szerző saját leíró-feltáró kutatásának bemutatása. Egy ezerfős reprezentatív minta és egy jogászi minta összehasonlításával a szerző egyik célja annak meghatározása, hogy a mai magyar társadalom miként vélekedik a jogalkotás és jogalkalmazás egyes kiemelt kérdéseiröl, miként látja az igazságszolgáltatás alapvető elveinek érvényesülését, mi a véleménye a bủnelkövetői magatartás okairól, a bűncselekmények áldozatává válásának kérdéséről, valamint a halálbüntetés indokoltságáról. További törekvése, hogy a jelenlegi igazságszolgáltatási rendszer megítélésében és elfogadottságában mutatkozó különbségeket feltárja. A kutatási eredményeket színes grafikonok, táblázatok szemléltetik, s egy összefoglaló táblázat rendszerezi. (T. A. N.)

- A börtön kultúrája - kultúra a börtönben

Korinek László - Köhalmi László (szerk.)

Pécsi Tudományegyetem Állam- és Jogtudományi Kar, Pécs, 2010.

Konferenciakötet. Terjedelem: 175. Bibliográfia az egyes tanulmányokban. ISBN 9789636423773.

- A kötet a Pécsett 2010 októberében tartott nemzetközi tudományos konferencia anyagát tartalmazza. A szerzők között Kovács Tamás akkori legföbb ügyész és egyetemi oktatók mellett számos büntetés-végrehajtásban dolgozó szakembert találunk. A tudományos tanácskozás igen érdekes témát járt körül: a büntetésvégrehajtási intézetek kulturális életét, a fogvatartottak kulturális, szabadidős lehetőségeit (pl. képzőművészeti szakkörök, színjátszás, freskóterápia) vizsgálta és értékelte. A konferenciakiadvány végén az olvasó fotók segítségével bepillantást nyerhet a fogvatartottak kreatív tevékenységeibe. (F. F.)

- Büntetőjog

Margitán Éva (szerk.)

ELTE Eötvös Kiadó, Budapest, 2010.

(Sorozat: ELTE Jogi Kari jegyzetek; 4.)

Tankönyv. Terjedelem: 461. Bibliográfia: 461. ISBN 9789633120101.

- A kötet szerzői egyetemi oktatók. Tankönyvük a büntetőjogi tankönyvek megszokott tematikáját követi, és nemcsak a büntetőjog általános részét, hanem a különös részét is tárgyalja egyben. Felépítése a készítésekor hatályos Büntető Törvénykönyvet követi, ennek köszönhetően jól átlátható az olvasó számára. A Különös Rész egyes fejezetei egy-egy táblázattal kezdődnek, melyek az adott fejezetben szabályozott bűncselekmények elmúlt évekbeli előfordulási számát mutatják. (T. A. N.)

- A magyar büntetőjog általános része

NAGY Ferenc

2., átdolgozott kiadás. HVG-ORAC, Budapest, 2010.

Tankönyv. Terjedelem: 477. Bibliográfia: 455-461. ISBN 9789632580982.

- A szerző egyetemi oktató. Tankönyve a büntetőjogi tankönyvek megszokott rendszerét követve hét nagy részben tekinti át a büntetőjog általános részének anyagát 
(bevezető tanok, jogszabálytan, a büncselekmény tana, jogkövetkezmény-tan, fiatalkorúak büntetőjoga, jogi személyekre vonatkozó rendelkezések és nemzetközi vonatkozások). A 2008-as első kiadáshoz képest a kötet a jogszabályi változásokkal és az új jogegységi döntésekkel is kiegészült. A könyv végén ajánlott irodalom, a latin kifejezések jegyzéke, valamint részletes név- és tárgymutató található. A Btk. és az egyéb törvények rendelkezéseit félkövér és dölt szedés emeli ki. (T. A. N.)

- Rendészettanulmányok a közbiztonságért. Tanulmányok a 60 éves Blaskó Béla tiszteletére

Németh Zsolt - Pallagi Anikó (szerk.)

Rendőrtiszti Főiskola, Budapest, 2010.

Tanulmánykötet. Terjedelem: 193. Bibliográfia a lábjegyzetekben. ISBN 978963 9543669.

- A kötetben Blaskó Béla rendőr vezérörnagyot, egyetemi oktatót köszöntik pályatársai és tanítványai egy-egy büntetőjogi tárgyú tanulmánnyal. A huszonnégy tanulmány között találunk a büntetőjog általános tanait és egyes büntetőjogi tényállásokat érintőt, alkotmányossági, rendészeti, büntetés-végrehajtási témájút, uniós joggal foglalkozót, magyar és angol nyelvüt egyaránt. Utószóként személyes hangvételü levél foglalja össze az ünnepelt szakmai és magánéletének föbb állomásait. A kötetet a jelentősebb szakmai eseményekről készített fényképválogatás zárja. (T. A. N.)

- Az ügyész szerepe az eljárásjogokban

Osztheimer Katalin (szerk.)

Károli Gáspár Református Egyetem, Budapest, 2010.

Konferenciakötet. Terjedelem: 118. Bibliográfia a lábjegyzetekben. ISBN 978963 9808201.

- A kiadvány a Károli Gáspár Református Egyetem által 2009 tavaszán azonos címmel megrendezett konferencián elhangzott előadások szerkesztett változatát tartalmazza. A közreadott nyolc tanulmányt egyetemi oktatók és gyakorló ügyészek jegyzik. Elsődleges céljuk az eljárásjog egyik kiemelkedő szereplője, az ügyész összetett feladatkörének bemutatása. A kötet szerkesztése az ügyészi feladatokhoz igazodik, így külön tanulmány foglalkozik a közvádlói szereppel, a büntetés-végrehajtási, valamint a közigazgatási és a magánjogi tevékenységgel. Az írásokat jogtörténeti kitekintés is gazdagítja. (T. A. N.)

\section{JOGTÖRTÉNET, RÓMAI JOG}

- Emlékkönyv Dr. Ruszoly József egyetemi tanár 70. születésnapjára

Balogh Elemér - Homoki-Nagy Mária (szerk.)

[Kiadó nélkül], Szeged, 2010.

(Sorozat: Acta Universitatis Szegediensis, ISSN 0324-6523; Acta juridica et politica, ISSN 0563-0606, Tom. 73., fasc. 1-64.) 
Tanulmánykötet. Terjedelem: 1018. Bibliográfia: 988-1014. és az egyes tanulmányok végén. ISBN 9789639927209.

- A kötet a Ruszoly József szegedi jogtörténész-professzor elötti tisztelgés jegyében született. Magyar jogászok mellett német, osztrák és szerb szerzők tanulmányai is megtalálhatók benne. A 63 tanulmány a betegjogoktól a büntetőjogi kodifikációkig, egy ókori római választási botránytól a kanadai jogrendszerbeli sajátosságokig a legkülönfélébb témaköröket dolgozza fel. A kötetet az ünnepelt rövid, német nyelvű életrajza és az 1959-2009 közötti munkásságáról készült bibliográfia zárja. (L. N.)

- Magyar állam- és jogtörténet

Csizmadia Andor - Kovács Kálmán - Asztalos László

15., változatlan kiadás. Nemzeti Tankönyvkiadó, Budapest, 2010.

Tankönyv. Terjedelem: 574. Bibliográfia az egyes fejezetek végén. ISBN 978963 1945669.

(L. N.)

- Magyar alkotmány- és jogtörténet

Degré Alajos

Béli Gábor (szerk.)

IDResearch-Publikon - PTE ÁJK, Pécs, 2010.

Egyetemi előadások. Terjedelem: 325. Bibliográfia nincs. ISBN 9789636619343.

- A könyv Degré Alajos előadásainak gyüjteménye, amelyeket a pécsi jogi egyetemen magyar állam- és jogtörténetböl az 1950/51-es tanévben tartott. A kötet hiánypótló, hiszen a régi jegyzet rossz minőségben és csak néhány példányban jelenhetett meg. A bevezető rész után az őskor, majd a középkor állam- és jogrendszerét mutatja be. A középkort tárgyaló rész jóval bővebb, ebben már részletesen megtalálható a társadalmi fejlődés, a gazdaságtörténet, a jogforrások, az igazságszolgáltatás, az egyházak vagy a magánjogtörténet intézményeinek bemutatása is. A harmadik rész a mohácsi vésztöl 1848-ig ugyanilyen elrendezés alapján, Erdély jog- és államrendszerének leírásával kiegészítve vázolja a korszak jog- és alkotmánytörténetét. A negyedik rész az utolsó száz év alkotmányjogával foglalkozik, kitérve hazánk Ausztriával és Horvátországgal való viszonyára is. (L. N.)

- Jurisprudentia splendidissima. Tanulmányok Nagyné Szegvári Katalin tiszteletére Az ELTE Állam- és Jogtudományi Kar Egyetemes Állam- és Jogtörténeti Tanszékének munkaközössége (szerk.)

Martin Opitz, Budapest, 2010.

(Sorozat: Bibliotheca luridica Libri Amicorum, ISSN 1587-1509; 37.; Acta Wenzeliana, ISSN 1786-0326; 8.)

Tanulmánykötet. Terjedelem: 222. Bibliográfia a lábjegyzetekben. ISBN nincs.

- A tanulmányok szerzői egyetemi oktatók. A kötettel az ELTE emeritus professzorát, a 2012-ben elhunyt Nagyné Szegvári Katalint köszöntötték 80. születésnapja alkalmából. A tíz tanulmány a jogtörténet legkülönfélébb területeit érinti: egyaránt 
találunk dolgozatot az antik római és görög jogi gondolkodás, a középkori Bajorország vagy a francia forradalom időszakáról, a magyar és amerikai jogfejlődés egy-egy területéröl és Bónis György pályafutásáról. (F. F.)

- A demokrácia katonái. A magyarországi polgári-alkotmányos átalakulás és szabadságharc belga megítélése 1848-1849-ben

ERDÖDY Gábor

ELTE Eötvös Kiadó, Budapest, 2010.

Monográfia. Terjedelem: 394. Bibliográfia: 379-386. ISBN 9789633120132.

- A szerző egyetemi oktató. A kötet az 1848-49-es magyar forradalom és szabadságharc belga megítélésével foglalkozik. Az első rész a bécsi belga rendkívüli követ meghatalmazott miniszter, Alphonse O'Sullivan De Grass 1848-49. évi jelentésében foglaltakat eleveníti fel. A kötetben a kora tavaszi forradalmaktól (1848. január-április 11.) a szabadságharc bukásáig (1849. július-augusztus) követhetjük nyomon a magyar szabadságharcot belga szemmel. A második rész a szerző által rendkívül részletesen kutatott hatalmas mennyiségủ belga politikai sajtóanyag vizsgálata alapján a szabadságharcról és a polgári átalakulásról levont következtetéseket tartalmazza. A munka számos levéltári anyagra, feldolgozásra, forráskiadványra és sajtóanyagra épül. (L. N.)

- A római jog története és institúciói

FöLDI András - HAMZA Gábor

15., átdolgozott és bővített kiadás. Nemzeti Tankönyvkiadó, Budapest, 2010.

Tankönyv. Terjedelem: 715. Bibliográfia a lábjegyzetekben. ISBN 978963196730.

- A szerzők egyetemi tanárok. A legtöbb magyarországi jogi karon használt római jogi tankönyvük 1996 óta jelenik meg. A mostani kiadásban az elmúlt évtizedek tapasztalatai alapján módosított szerkezettel, bővebb és átdolgozott név- és címmutatóval, illetve szakirodalmi tájékoztatóval jelentkeztek. (L. N.)

- A magyar királyi kegyúri jog Szent Istvántól Mária Teréziáig. Történeti tanulmány FRAKNól Vilmos

Reprint. Históriaantik Könyvesház, Budapest, 2010.

Monográfia. Terjedelem: 559. Bibliográfia a lábjegyzetekben. ISBN nincs.

- A szerző történetíró, kanonok, az MTA titkára volt (1843-1924). E reprint kiadásban közreadott múve, amely eredetileg 1895-ben jelent meg, a katolikus egyház és a királyság közötti egyik szoros kapcsolódási pont, a királyi kegyuraság intézménye történetével foglalkozik. A Szent István és Mária Terézia uralkodása között eltelt majd 800 év történéseit hét fejezetben tekinti át. Vatikáni levéltári iratok alapján rekonstruálja - különösen a mohácsi vész utáni időszakból - a Szentszék és a magyar királyi udvar közötti, a királyi kegyúri jogok iránt folyó diplomáciai tárgyalásokat. A szerző kitér az intézmény más európai államokban megfigyelhető sajátosságaira is. (F. F.) 
- A magyar bírósági szervezet és perjog az Árpád- és a vegyes-házi királyok alatt HAJNIK Imre

Reprint. Históriaantik Könyvesház, Budapest, 2010.

Monográfia. Terjedelem: 454. Bibliográfia a lábjegyzetekben. ISBN 599000097 4270.

- A szerző jogtudós, jogtörténész, a Magyar Tudományos Akadémia tagja volt (18401902). 1899-ben készült munkája a magyar bírósági szervezetet és a perjogot vizsgálja az Árpád-házi királyoktól a mohácsi vészig. A könyv a maga idejében hiánypótló volt: elsőként foglalta össze a középkori magyar perjogot, négy részben. A bírósági szervezet bemutatása után a per részletezése következik, melyet a bizonyítási rendszer bemutatása követ. Végül a per egyéb alkatrészei (ítélet, egyezség, perorvoslatok, perbeli vétségek, bírságok) következnek. A munka kiterjed a horvát-szlavón-erdélyi-dalmát-tót és a végvidéki jog vizsgálatára is. A végén megtaláljuk a perjogi latin müszavak jegyzékét is. (L. N.)

\section{- Magyar alkotmány és jog az Árpádok alatt}

HAJNIK Imre

Reprint. Históriaantik Könyvesház, Budapest, 2010.

Monográfia. Terjedelem: 377. Bibliográfia a jegyzetekben. ISBN 5990000712551.

- A szerző jogtudós, jogtörténész, a Magyar Tudományos Akadémia tagja volt (18401902). 1872-ben készült munkája a középkori magyar alkotmánytörténetet mutatja be, négy könyvre tagolva. Az ősmagyar nemzetségi szervezettől, majd a rómaiaktól az avarokon, hunokon és más népeken keresztül a magyar nép megjelenéséig és letelepedéséig tekinti át a kezdeti korszakot a Kárpát-medencében. A Szent István-i államszervezet aranykora, majd hanyatlása után a jogélet részletes leírásával zárul a munka, átfogva a családjogtól a tulajdonjogon át a büntetőjogot is. (L. N.)

- Iura antiqua ac iura moderna methodo comparativa investigata - Opera selecta. Ausgewählte Schriften zur antiken Rechtsgeschichte, zur Rechtsvergleichung und zum geltenden Recht I.

HAMZA Gábor

Eötvös Kiadó, Budapest, 2010.

Válogatott előadások. Terjedelem: 337. Bibliográfia az egyes tanulmányok végén. ISBN 9789632841359.

- A szerző akadémikus, egyetemi tanár. A kötetben 60. születésnapja alkalmából az idegen nyelven (németül, franciául, olaszul és spanyolul) megjelent, a római jog és továbbélése témakörével foglalkozó, válogatott tanulmányai jelentek meg. A magyar és német nyelvű előszó után a tanulmányok három fejezetre tagolva olvashatók. Az első fejezet a római jog és az antikvitás viszonyával, a második a római jog továbbélésével foglalkozik. A harmadik fejezet „variációk” cím alatt egy olasz nyelvü tanulmányt tartalmaz a római jog középkori tanításáról az olasz és magyar egyetemeken, illetve egy német nyelvü tanulmányt a római jognak a harmadik birodalom és a nácizmus gondolkodásmódjában és filozófiájában betöltött szerepéröl. A gyűjtemény második kötete 2011-ben jelent meg. (L. N.) 
- Mezővárosaink jogélete a 18-19. században

Homoki-Nagy Mária (szerk.)

Pólay Elemér Alapítvány, Szeged, 2010.

(Sorozat: A Pólay Elemér Alapítvány könyvtára, ISSN 1786-352X; 2.)

Tanulmánykötet. Terjedelem: 158. Bibliográfia az egyes tanulmányok végén. ISBN 9789639650480.

- A szerzők egyetemi oktatók, jogtörténészek. A kötet a 18-19. századi magyar közigazgatás-történet egy rendkívül érdekes korszakáról készült tanulmányok válogatását adja közre. A szerzők az ország különböző tájegységein található mezővárosokról készítették tanulmányaikat, így helyet kapott a könyvben Debrecen, Makó, Pest, Bihar vagy az Alföld is. Kecskemét városrendészeti szabályozásától a szolgabírói szék békési bíráskodásáig találunk témaköröket a könyvben. A kötet az SZTE immár hagyományos, kétévenkénti konferenciáinak első rendezvényén elhangzott előadások alapján készült. (L. N.)

- Die Habsburgermonarchie auf dem Wege zum Rechtsstaat?

Máthé Gábor - Ogris, Werner (szerk.)

Magyar Közlöny Lap- és Könyvkiadó, Budapest-Bécs, 2010.

Tanulmánykötet. Terjedelem: 328. Bibliográfia az egyes tanulmányok végén. ISBN 9789639722774.

- A szerzők magyar, osztrák, cseh és lengyel jogtörténészek. A kötetben a 2008 májusában Bécsben, „A Habsburg Monarchia a jogállamiság útján?” címmel, az Österreichische Akademie der Wissenschaften és a Magyar Tudományos Akadémia által rendezett, nemzetközi jogtörténeti konferencia szerkesztett anyaga található. A kötet tíz tanulmányt tartalmaz a Habsburg Monarchia történetéröl, többek között a Batthyány Lajos elleni perről, a kiegyezés kori börtönügyi szabályozásról, a legfelső bíróságok ítélkezési gyakorlatáról vagy az állampolgári jogokról. Az osztrák szerkesztő bevezető tanulmánya a jogállam fogalmának kialakulásával foglalkozik. A kötetben közreadott valamennyi tanulmány német nyelvü. (F. F.)

- Előadások a magyar alkotmánytörténet köréből

Megyeri-Pálffi Zoltán (szerk.)

Debreceni Egyetemi Kiadó, Debrecen, 2010.

Tansegédlet. Terjedelem: 104. Bibliográfia: 104. ISBN 9789633180846.

- A szerzők egyetemi oktatók. A joghallgatók számára készült tansegédlet tizenkét előadása a magyar állam kialakulásától az 1944 utáni időszakig követi nyomon a magyar alkotmánytörténet fejlődését. Ábrákat, rajzokat, táblázatokat, felsorolásokat és önellenőrző kérdéseket is tartalmaz, melyek megkönnyítik a tananyag elsajátítását. (L. N.)

- Régi idők tömlöcei. Büntetések, börtönök, bakók

Mezey Barna

Rubicon-Ház, Budapest, 2010.

Kézikönyv. Terjedelem: 175. Bibliográfia: 173-175. ISBN 9789639839069. 
- A szerző egyetemi tanár. Jelen munkája a börtönök, tömlöcök és az ítélet-végrehajtás történetével foglalkozik. Az őskortól egészen a 18-19. századig követi a börtönök szerepét nemcsak hazánkban, hanem Európában is. Külön fejezetben foglalkozik az egyházi börtönökkel és kínzókamrákkal, illetve a hóhér szerepével. A kötet kultúrtörténeti értékét a nagyszámú fekete-fehér és színes illusztráció emeli. (L. N.)

- Degré Alajos emlékezete. Tudományos emlékülés, Zalaegerszeg, 2009. május 14. Molnár András (szerk.)

Magyar Közlöny Lap- és Könyvkiadó - Zala Megyei Levéltár, Budapest-Zalaegerszeg, 2010.

Konferenciakötet. Terjedelem: 274. Bibliográfia fejezetenként. ISBN 9789639722 880.

- A szerzők jogtörténészek, levéltárosok, történészek; kötetük Degré Alajos (19091984), a jeles jogtörténész és levéltáros emlékére készült. A benne közölt 12 tanulmány a 2009. május 14-én (Degré születésének 100. évfordulóján, annak szülővárosában), Zalaegerszegen tartott emlékülésen elhangzott 12 előadás szerkesztett változata. Témáik változatosak: Degré jogtörténészi munkásságáról éppúgy találunk dolgozatot, mint az igazságszolgáltatás vagy az ügyészség, illetve a zalaegerszegi megyei tömlöc történetéről. Unokaöccsének visszaemlékezéseiböl Degré személyes oldalát is megismerhetjük. A kötet az emlékülés fényképeit is tartalmazza. (L. N.)

- A magyarországi várispánságok története, különösen a XIII. században Pesty Frigyes

Históriaantik Könyvesház, Budapest, 2010. (Reprint) Monográfia. Terjedelem: 591. Bibliográfia a lábjegyzetekben. ISBN nincs.

- A szerző történész, helynévkutató, a Magyar Tudományos Akadémia tagja volt (1823-1889). Ismét közreadott múve eredetileg 1882-ben jelent meg. A kötet első része a várispánsági intézményt mutatja be, így kitér az ispánságok eredetére, számára, fekvésére, a várispánságok osztályaira és tisztjeire, hadirendszerükre és a városok fejlődésére gyakorolt hatására. A második, „A várispánságok külön leirása" címü rész a 82 magyar várispánság középkori történetét ismerteti. (F. F.)

- A perdöntö bajvivások története Magyarországon

PESTY Frigyes

Reprint. Históriaantik Könyvesház, Budapest, 2010. Monográfia. Terjedelem: 192. Bibliográfia a lábjegyzetekben. ISBN nincs.

- A szerző történész, helynévkutató, a Magyar Tudományos Akadémia tagja volt (1823-1889). E müve eredetileg 1867-ben jelent meg, s benne a középkorban ismert „ordaliák” (istenítéletek) egyik fajtáját, a bajvívást vizsgálja. Áttekinti a bajvívások eredetét és elterjedését, törvényeit, kitér a viadorok és a bírák személyére, a bajvívás alóli felmentésre, a papság általi megítélésre és az ítélethozatalra. A kötet végén a "nevezetesebb bajviadalokat” ismerteti. (F. F.) 
- Az eltünt régi vármegyék I-II.

PESTY Frigyes

Reprint. Históriaantik Könyvesház, Budapest, 2010.

Monográfia. Terjedelem: 434 (I. kötet), 509 (II. kötet). Bibliográfia a lábjegyzetekben. ISBN nincs.

- A szerző történész, helynévkutató, a Magyar Tudományos Akadémia tagja volt (1823-1889). E kétkötetes múve eredetileg 1880-ban jelent meg. Az 1184 és 1241 között Magyarországon létezett vármegyéket mutatja be földrajzi fekvésük szerinti sorrendben. Az első kötet bevezető tanulmánya kiindulópontként tisztázza a vármegye fogalmát, és bizonyítja (különféle történeti források eltérő adatainak és a szakirodalmi nézeteknek a kritikai elemzésével), hogy a vizsgált időszakban 72 vármegye létezett. (F. F.)

- A magyar állam története, 1711-2006

Szabó Pál Csaba (szerk.)

Bölcsész Konzorcium - JATEPress, Szeged, 2010.

Tankönyv. Terjedelem: 447. Bibliográfia: 441-447. ISBN 9789639704083.

- A szerzők egyetemi oktatók, történészek. A felsőoktatásból évek óta hiányzó magyar államtörténeti tankönyvet adnak közre, amely a modern magyar állam 18. századi differenciálódásának, 19. századi megerősödésének és 20. századi átváltozásának háromszáz éves történetét mutatja be. Az egyes korszakokat áttekintő fejezetek vizsgálják a legfontosabb állami szervezetek és intézmények kialakulását, az alkotmányosság alakulását, a törvényhozás, a kormányzat és az igazságszolgáltatás szerveit, az állami működést meghatározó jogszabályi környezetet. A tananyag elsajátítását nagymértékben segíti a magyar állam 1711 és 2006 közötti eseményeinek kronológiája és az államtörténeti fogalomtár. (F. F.)

- A Rákos mezei országgyülések története

SzEnde László

Papcsák Ügyvédi Iroda, Budapest, 2010.

Tanulmány. Terjedelem: 93. Bibliográfia: 61-67. ISBN 9789630690515.

- A szerző történész. Jelen tanulmánya a Rákos mezeje névvel illetett (ma Zuglóként ismert) területen 1277 és 1526 között lezajlott magyar történelmi eseményeket eleveníti fel, egyúttal áttekintést is ad a korabeli viszonyokról és közjogi aktusokról. Bemutatja a törvényhozás színtereit, az országgyűlések tárgyalási rendjét, illetve az országgyűlés közjogi szerepét, különös tekintettel a törvényhozásra és a királyválasztásra. A szerző közreadja az ismertetett események számos korabeli leírását is. A kötetet korabeli metszetek, térképek, miniatúrák illusztrálják. (F. F.)

- A történeti alkotmány: Magyarország ősi alkotmánya

ZÉTÉNYI Zsolt (szerk.)

2., bővített kiadás. Magyarországért Kulturális Egyesület, Budapest, 2010.

Dokumentumgyüjtemény. Terjedelem: 1407. Bibliográfia: 1367-1376. ISBN 978 9630687034. 
- A szerkesztő jogász, volt országgyülési képviselő. Teljes szöveggel közli a magyar történeti alkotmány törvényeit és szokásait a vérszerződéstől az 1942. évi XXI. törvénycikkig. A terjedelmes bevezető tanulmány körüljárja az alkotmány fogalmát, a történeti alkotmány jellegzetességeit, forrásait és föbb sarokpontjait. A kötet tematikus és időrendi áttekintést is ad a törvényekröl, mellékletében pedig számos listát közread többek között Magyarország királyairól, nádorairól, országbíráiról vagy a Koronaőrség névsoráról. Ábrákkal szemlélteti Magyarország államszervezetét az egyes korszakokban, valamint részletes név- és tárgymutatót és kifejezésjegyzéket, illetve egy hosszabb angol nyelvű összefoglalót is tartalmaz. (F. F.)

\section{MUNKAJOG, SZOCIÁLIS JOG}

- A Munka Törvénykönyve 2010, egységes szerkezetben állásfoglalásokkal és magyarázatokkal

BREZnAY Tibor

7., bővített kiadás. KOMPKONZULT, Budapest, 2010.

Kommentár. Terjedelem: 566. Bibliográfia nincs. ISBN 9789639427754.

- A szerző gyakorló bíró, egyetemi oktató. A kötetben a Munka Törvénykönyve 2010 januárjában hatályos szövegét tekinti át, ismertetve a vonatkozó munkaügyi kollégiumi állásfoglalásokat és egyes munkaügyi bírósági határozatokat. Kitér a vonatkozó nemzetközi és uniós jogi kötelezettségekre és a kapcsolódó magyar jogszabályi rendelkezésekre (pl. az esélyegyenlőség vagy a bírósági igényérvényesítés körében). A kötet szerkezetében az Mt. egyes fejezeteit követi, az áttekinthetőséget nagyban segítik a félkövér kiemelések és az eltérő betűméretek. (F. F.)

- Szociális jog II.

Hajdú József - Homicskó Árpád Olivér (szerk.)

Patrocinium, Budapest, 2010.

(Sorozat: Bethlen-sorozat, ISSN 2062-2546)

Tankönyv. Terjedelem: 278. Bibliográfia nincs. ISBN 9789638905192.

- A szerzők kutatók, illetve oktatók; könyvük elsősorban a felsőoktatásban tanuló hallgatóknak szól. Először az egészségbiztosítási rendszert elemzik, rendszerezve az ahhoz tartozó ellátásokat. Ezt követi a nyugdíjbiztosítás rendszere, ahol kidomborodik az önkéntesség elemének erősödése (erre pl. az előtakarékossági számla és a foglalkoztatói nyugdíjszolgáltatás intézményeinek meghonosítása). A szerzők a foglalkoztatáspolitikát, a szociális jogi és a családtámogatási rendszert az előzőekhez hasonló részletességgel festik le. Valamennyi téma vonatkozásában elmondható, hogy a szerzők a tankönyvi kereteket meghaladó, értékelő véleményt is adnak. (D. D.) 
- Rendszerváltás a munkaügyben

Halmos Csaba

PTE Felnőttképzési és Emberi Erőforrás Fejlesztési Kar, Pécs, 2010.

Kézikönyv/Monográfia. Terjedelem: 384. Bibliográfia: 375-384. és a lábjegyzetekben. ISBN 9789636423599.

- A szerző egyetemi oktató, munkaügyi szakember. Könyve a szocialista korszak utolsó éveinek a hazai munkaügy területén tapasztalható változásait elemzi; többek között a foglalkoztatáspolitika, a szociális jog, a bérezés és az érdekegyeztetés rendszerét körüljárva. A munkaügyi „rendszerváltozást” nemcsak munkajogi, hanem közgazdaságtani és társadalmi aspektusból is vizsgálja, kitérve a nemzetközi kapcsolatok jelentőségére is. A könyv melléklete számos, a témát illusztráló dokumentumot tartalmaz (pl. OÉT-ülések, SZOT-Kormány tanácskozások összefoglalói, szakszervezeti és szakértői vélemények jogalkotási tervezetekröl stb.). (D. D.)

\section{- Alapjogok kollíziója a munkajogban}

Kıss György

Justis Bt., Pécs, 2010.

Kézikönyv. Terjedelem: 668. Bibliográfia: 585-635. ISBN 9789638910806.

- A szerző egyetemi oktató. A kötet elsősorban az alapvető jogok érvényesülését vizsgálja a munkajog területén, az erről szóló fejezetet azonban megelőzi egy általános alapjogi dogmatikai fejezet, amely az emberi méltóságtól indulva a szociális jogok, az alapjogok hatálya és az alapjogi kollízió kérdéseit vizsgálja. A második, központi fejezet az alapjogok kollízióját külön vizsgálja az individuális és a kollektív munkajogban. A szerző következtetéseit önálló fejezetben foglalja össze. A kötetet angol és német nyelvü összefoglaló, terjedelmes irodalomjegyzék, jogesetjegyzék, név- és tárgymutató zárja. (D. D.)

- Fontosabb változások a tanügyi és a közoktatást érintő munkajogi szabályozás terén: kommentár és tételes normaszöveg-gyüjtemény a jogszabályváltozások értelmezéséhez

KozÁk András

L'Harmattan, Budapest, 2010.

Kommentár. Terjedelem: 404. Bibliográfia nincs. ISBN 9789632363363.

- A szerző pedagógus. E kötettel a közoktatásban részt vevőknek kíván segítséget nyújtani a tanügyigazgatás és a közoktatásra vonatkozó munkajogi szabályozás áttekintésével. Igyekszik közérthetően elmagyarázni a bonyolult és szerteágazó jogszabályi változások lényegét, s az ezekböl fakadó teendőket. A kötet a normaszöveg-változások jól nyomon követhető, forrásokkal alátámasztott vázlatát adja, a két meghatározó ágazati jogszabály teljes, változásokkal egységbe foglalt, 2010ben hatályos szövegével.

- Munkaügyi kézikönyv szociális intézmények számára Köszegfalvi Edit

CompLex, Budapest, 2010.

Kézikönyv. Terjedelem: 643. Bibliográfia nincs. ISBN 9789632950990. 
- A szerző jogász. A kézikönyv a szociális ágazatban dolgozó közalkalmazottak számára a napi munkavégzés során felmerülő jogalkalmazási, illetve munkajogi problémák megoldásához kíván segítséget nyújtani, gyakorló jogászi megközelítésben. A könyv a joganyag ismertetésén és a hozzá kapcsolódó magyarázaton keresztül, illetve példák bemutatásával segíti az eligazodást. Felépítése követi a közalkalmazotti törvény szerkezetét, és az egyes témaköröket fejezetekre osztva mutatja be az egyes jogintézményeket.

- Pedagógusok munkaügyi kézikönyve

Köszegfalvi Edit

CompLex, Budapest, 2010.

Kézikönyv. Terjedelem: 632. Bibliográfia nincs. ISBN 9789632950884.

- A szerző jogász. A kötetben a közoktatásra vonatkozó joganyagot tekinti át, amelyhez folyamatosan frissülő online szolgáltatás is igénybe vehető. Gyakorló jogászi megközelítésben a közoktatási intézmények számára kíván segítséget nyújtani a napi munkavégzés során felmerülő jogalkalmazási, munkajogi problémák megoldásához. Ezt szolgálja az egyes jogintézmények alkalmazása során, a közoktatás területén naponta jelentkező kérdések felvetése és az azokra adandó válaszok megadása.

- Szociális jog II.: Európai és magyar foglalkoztatás támogatási és munkaügyi, valamint munkavédelmi igazgatási jog. Társadalombiztositási jog

Prugberger Tamás - Tóth Hilda (szerk.)

2., átdolgozott kiadás. Novotni, Miskolc, 2010.

Egyetemi jegyzet. Terjedelem: 281. Bibliográfia nincs. ISBN 9789639360495.

- A szerzők a Miskolci Egyetem oktatói, jelen munkájuk a társadalombiztosítási jogot áttekintő korábbi tankönyv hatályosított változata. A társadalombiztosítás hazai történetének és rendszerének felvázolását követően külön foglalkoznak az egészség- és nyugdíjbiztosítási szolgáltatásokkal, a családtámogatási rendszerrel, az azokhoz kapcsolódó fogalmak (pl. biztosítási jogviszony, baleset, rokkantság) értelmezésével. Kitérnek a finanszírozás kérdéseire is.

\section{NEMZETKÖZI JOG, EURÓPA-JOG}

\section{- A nemzetközi légiközlekedés védelme}

ERNSzT lldikó

Károli Gáspár Református Egyetem Állam- és Jogtudományi Kar, Budapest, 2010. Monográfia. Terjedelem: 196. Bibliográfia: 185-196. ISBN 9789639808232.

- A szerző egyetemi oktató. A nemzetközi légi közlekedés 2001 óta történt visszaesésének apropóján átfogóan foglalkozik a légi közlekedés nemzetközi történeti hátterével, szabályozásával, a kapcsolódó egyezményekkel, nemzetközi szervezetekkel, és számos konkrét esetet is elemez. Külön fejezetben vizsgálja a repülésbiztonság megteremtésének alaplépéseit az USA-ban, az Európai Unióban és Magyarországon. Az emberi jogok és a repülésvédelem kapcsolatát is tárgyalja, 
kitérve a terrorizmus, az adatvédelem, a repülőtereken alkalmazott megalázó bánásmód és a faji alapon történő megkülönböztetés kérdéseire. A kötet melléklete tartalmazza a légi közlekedéssel kapcsolatos egyezményeket kihirdető és a légi közlekedés védelmével kapcsolatban elfogadott magyar jogszabályok, illetve a vonatkozó ENSZ közgyülési és biztonsági tanácsi határozatok jegyzékét. (P. A.)

- Liber Amicorum Prandler Árpád: Tanulmányok Prandler Árpád 80. születésnapja alkalmából

Lamm Vanda (szerk.)

Lectum, Budapest, 2010.

Tanulmánykötet. Terjedelem: 135. Bibliográfia a végjegyzetekben. ISBN 978963 0801652.

- Az ünnepelt a Nemzetközi Törvényszék bírája, egyetemi oktató; a szerzők a szakmabeli barátai, tanítványai. A kötet a Prandler Árpád 80. születésnapja alkalmából, a Magyar Tudományos Akadémián rendezett konferencia elöadásait tartalmazza, továbbá megtalálható benne Prandler Árpád fontosabb publikációinak a jegyzéke is. Az egyes tanulmányok számos nemzetközi jogi területet érintenek, mind elméleti (a nemzetközi jog strukturális változásai, jövőbeni kihívásai, a nemzetközi kapcsolatok átalakulása), mind gyakorlati (az ENSZ szerepe a Balkánon, a Duna megjelenése a nemzetközi egyezményekben, az ICTY és a Biztonsági Tanács, kisebbségvédelem mint világprobléma) szinten. (P. A.)

- A politika tudománya. Nemzetközi politika, Európa-politika, nemzetpolitika Moнı Csaba

PPKE JÁK, Budapest, 2010.

(Sorozat: A Pázmány Péter Katolikus Egyetem Jog- és Államtudományi Karának tankönyvei, ISSN 2062-0837)

Tankönyv. Terjedelem: 332. Bibliográfia: 329-332. ISBN 9789633080160.

- A szerző egyetemi oktató. Tankönyvének elsődleges tárgya a nemzetközi politika tudománya, e kérdéskört azonban az Európa-politika és a nemzetpolitika dimenziójában is tárgyalja. Kiinduló tézise egy müködőképes, a világpolitikában is sikeres egyesült Európa szükségessége. Erre tekintettel a könyv az európai integráció történetének, jogegységesítő törekvéseinek, bővítéseinek, közös kül- és biztonságpolitikájának áttekintésén túl részletesen elemzi az uniós tagállamok érdekérvényesítő törekvéseit és módszereit, illetve az egységes Európa érvényesülési lehetőségeit a globális világrendben. (F. F.)

- Essential EU Law in Charts

Tobler, Christa - Beglinger, Jacques

2. kiadás. HVG-ORAC, Budapest, 2010.

Tankönyv. Terjedelem: 363. Bibliográfia nincs. ISBN 9789632580869.

- A szerzők a leideni, illetve a bázeli egyetem oktatói. A Lisszaboni Szerződés újitásaira tekintettel frissített kötetük a két egyetem Európa-jogi intézeteinek összefogásával futó „The EU Law in Charts Project” keretében jelent meg, amely az uniós jog közérthetőbbé tételét célozza. A kötet ennek jegyében 12 fejezetben tekinti át 
az uniós jog vázlatát úgy, hogy leírások helyett szemléltető ábrákkal, folyamatábrákkal és táblázatokkal magyarázza az egyes témaköröket. A kötetben foglaltak megértését segíti az „Essential EU Law in Text” címü kísérőfüzet. (F. F.)

- Essential EU Law in Text

Tobler, Christa - Beglinger, Jacques

HVG-ORAC, Budapest, 2010.

Tankönyv. Terjedelem: 122. Bibliográfia nincs. ISBN 9789632580876.

- A szerzők a leideni, illetve a bázeli egyetem oktatói. A kötet az „Essential EU Law in Charts" című munka kísérőfüzete, amely a Lisszaboni Szerződéssel módosított uniós alapszerződések rendelkezéseit és egyes vonatkozó uniós jogszabályokat tekinti át magyarázó ábrák, táblázatok segítségével. A szerzők a két kötet együttes használatát javasolják, ugyanis a jelen munka a szerződések és jogszabályok egyszerüsített szövegében folyamatosan utal a másik kötetben található vonatkozó ábrá(k)ra. A kötet öt témakört dolgoz fel: az EU jogi alapjait, gazdasági jogát, szociális jogát, az integrációs megoldásokat és az uniós jog kikényszeríthetőségét. (F. F.)

\section{POLGÁRI JOG, POLGÁRI ELJÁRÁSJOG}

- A gazdasági jog alapjai

Aszódi llona

Perfekt, Budapest, 2010.

Főiskolai jegyzet. Terjedelem: 293. Bibliográfia nincs. ISBN 9789633946275.

- A szerző főiskolai oktató. Munkája a gazdasági jog vázlatos áttekintését nyújtja leendő gazdasági szakembereknek. Elsőként Magyarország nemzetközi kapcsolatait tárgyalja, majd a gazdasági társaságok általános szabályait ismerteti. $\mathrm{Az}$ olvasó ezt követően az egyes gazdasági társaságokra, a szövetkezetekre és a nonprofit szervezetekre vonatkozó anyagi és eljárási szabályokba nyerhet betekintést, és megismerheti az egyéni vállalkozóra vonatkozó legfontosabb joganyagot. A kötet felvázolja a cégbejegyzés folyamatát, a fizetésképtelenségi eljárásokat, illetőleg a végelszámolás menetét is. (B. L.)

- Magyar fogyasztóvédelmi és reklámjog

Balogh Virág - Kaszainé Mezey Katalin - PÁZmÁnd Kinga - ZavodnYIK József HVG-ORAC, Budapest, 2010.

Kézikönyv. Terjedelem: 345. Bibliográfia nincs. ISBN 9789632580951.

- A szerzők gyakorló jogászok; kötetük a versenyjog, a fogyasztóvédelmi és reklámszabályozásról nyújt átfogó képet. Feltárja az említett tárgyköröknek a versenytörvényhez való kapcsolódási pontjait, és elhatárolási kérdésekre is kitér. A kézikönyv szükségességét a vázolt témák szabályozásában 2008-tól kezdődő átrendeződés igazolja: a fogyasztók elleni tisztességtelen kereskedelmi gyakorlatok tilalmáról új törvény született, az 1997-es reklámtörvényt átdolgozta a jogalkotó; a változások 
több speciális és ágazati jogszabályt érintettek. A versenytörvény egyes fejezetei új szabályozási környezetbe kerültek és az antitrösztjogban is módosításokat hajtottak végre, valamint 2009-ben a Magyar Reklámetikai Kódex is megújult. (T. É.)

- Az ingatlanjog nagy kézikönyve

Bedö Katalin - HIDASI Gábor - HoRVÁtH Gyula - KöszEgI Gábor

2. kiadás. CompLex, Budapest, 2010.

(Sorozat: Meritum, ISSN 1788-6198)

Kézikönyv. Terjedelem: 1253. Bibliográfia nincs. ISBN 9789632249919.

- A szerzők gyakorlati jogászok; tapasztalataikból is merítve olyan kézikönyvet bocsátottak közre, amely egy helyen és rendszerezve gyüjt össze minden, az ingatlanjoggal kapcsolatos információt. A kézikönyv 16 részben ismerteti az ingatlanokat érintő jogi szabályozás valamennyi lényeges elemét; az ingatlanjog fogalmától kezdve, az ingatlanra vonatkozó szerződéseken és az ingatlanra történő végrehajtáson keresztül a vonatkozó nemzetközi magánjogi és uniós szabályokig. Az elméleti ismeretanyagot összekapcsolja a gyakorlati tudnivalókkal. (B. L.)

- Polgári jog. Személyek joga

BESENYEI Lajos - BíRó György

[3. kiadás] Novotni, Miskolc, 2010.

Egyetemi jegyzet. Terjedelem: 201. Bibliográfia nincs. ISBN nincs.

- A szerzők egyetemi oktatók. Jegyzetük a Polgári Törvénykönyv Személyek címü förészében foglalt szabályokkal foglalkozik, ezen belül a természetes személyekre vonatkozó szabályokkal (jogképesség, cselekvőképesség), a jogi személyekre vonatkozó általános rendelkezésekkel és kiemelten a fontosabb, más jogágban nem tárgyalt jogi személyek müködésére vonatkozó rendelkezésekkel, tehát az úgynevezett jogalany szervezetekkel és a személyhez füződő jogok polgári jogi védelmével. (T. I. Á.)

- Hol tartunk? A civil nonprofit szervezetek jogi szabályozásának problémái Bíró Endre Jogismeret Alapítvány, Budapest, 2010.

Tanulmány. Terjedelem: 87. Bibliográfia: 85-87. ISBN 9789638896506.

- A szerző a Jogismeret Alapítványnál tevékenykedő jogász. Jelen tanulmánya az alapítvány azonos című, a szerző által irányított kutatási projektje keretében készült. Az alapítvány internetes honlapján is teljes terjedelmében elérhető. A civil szervezetek jogi szabályozásának történeti áttekintését követően összegzi az elmúlt évtized e témában született irodalmát és az ezekben megfogalmazott javaslatokat, probléma- és tárgyköröket. Az eddigi tapasztalatok, a gyakorlat jelzései és a kapcsolódó jogirodalmi válaszok alapján jogalkotási javaslatokat tesz a szabályozás jövőbeni irányvonalára. (B. L.) 
- Magyar polgári jog: Általános tanok

Bíró György - Lenkovics Barnabás

8., átdolgozott kiadás. Novotni, Miskolc, 2010.

Egyetemi jegyzet. Terjedelem: 229. Bibliográfia: 221-223. ISBN nincs.

- A szerzők egyetemi oktatók. Tankönyvük elsősorban a polgári jogi tanulmányaikat kezdő egyetemi hallgatóknak nyújt segítséget az alapvető polgári jogi ismeretek elsajátításához. A kötet Novotni Zoltán azonos című könyvének anyagát dolgozza fel, annak koncepcióját megtartva, öt fejezetben. Szemléletes példákon keresztül mind a dogmatika (az alapfogalmak), mind a hatályos szabályok ismertetésére sor kerül. (T. I. Á.)

- Magyar polgári jog: a Polgári Törvénykönyv a bírói gyakorlattal

Bíró György (szerk.)

Novotni, Miskolc, 2010.

Egyetemi jegyzet. Terjedelem: 246. Bibliográfia nincs. ISBN nincs.

- A szerkesztő egyetemi oktató. Tankönyve a Polgári Törvénykönyv és a vonatkozó bírósági határozatok ismertetését célozza. Összefoglalja a polgári anyagi joghoz kapcsolódó valamennyi jelentős ítéletet (amelyek a BH-ban, BDT-ben, IH-ban megjelentek), valamint a Legfelsőbb Bíróság elvi és jogegységi döntéseit, illetve a Polgári Kollégium állásfoglalásait. (T. I. Á.)

- Ünnepi tanulmányok Balásházy Mária tiszteletére

BodzÁsı Balázs (szerk.)

BCE Gazdasági Jogi Intézet, Budapest, 2010.

Tanulmánykötet. Terjedelem: 381. Bibliográfia a jegyzetekben és a fejezetek végén. ISBN 9789635034208.

- A szerzők jogászok és közgazdászok, többnyire az ország különböző egyetemeinek oktatói. A tanulmánykötet Balásházy Máriának, a Budapesti Corvinus Egyetem 60 esztendős oktatójának a tiszteletére készült, s föként gazdasági jogi, polgári jogi, illetve köz-, környezet- és vállalatgazdaságtani tárgyú tanulmányok kaptak helyet benne. A jogtudományi írások egyaránt érintik a civilisztika általános és speciális tárgyköreit (pl. a jogügyletek, a jogi személyiség nélküli társaságok, a konzorciális hitelnyújtás biztosítékai vagy a projekttársaságok aktuális kérdéseit). (T. I. Á.)

- Polgári jog I. Polgári jogi alapfogalmak, Személyek joga, Dologi jog CsÉCsy Andrea - Csécsy György - SzIKORA Veronika 2., átdolgozott kiadás. A Debreceni Egyetem Állam- és Jogtudományi Kar Polgári Jogi Tanszékének kiadványa, Center Print, Debrecen, 2010.

Egyetemi jegyzet. Terjedelem: 202. Bibliográfia: 201-202. ISBN 978963473427 7.

- A szerzők a Debreceni Egyetem Állam- és Jogtudományi Karának oktatói. A könyv tartalmát és terjedelmét tekintve is egy redukált, sürített tananyagot tartalmaz, amely a nem jogász szakos hallgatók számára ad eligazítást a polgári jog szabályainak rendszerében. Az áttekinthető, hallgatóbarát kötetben a polgári jogi alap- 
fogalmakat a személyek jogának bemutatása követi, majd a dologi jogra vonatkozó rendelkezések jelennek meg. (T. É.)

\section{- Polgári jog II. Kötelmi jogi alapok}

CsÉcsy Andrea - Csécsy György - SzIKora Veronika

2., átdolgozott kiadás. A Debreceni Egyetem Állam- és Jogtudományi Kar Polgári Jogi Tanszékének kiadványa, Center Print, Debrecen, 2010.

Egyetemi jegyzet. Terjedelem: 160. Bibliográfia: 160. ISBN 9789634734284.

- A szerzők egyetemi oktatók. A könyv a Polgári jog I. c. kötetet egészíti ki a kötelmi jog alapvető szabályaival, beleértve a szerződések általános előírásait, a polgári jogi felelősségre vonatkozó rendelkezéseket, továbbá az egyes szerződéstípusokat. Ezáltal a Polgári jog I. és II. kötetek egymáshoz szervesen illeszkedve lefedik - az öröklési jog kivételével - a polgári jog teljes anyagát. Figyelemmel arra, hogy a szerzők célja egy egyszerüsített és lényegre törekvő tananyag összeállítása volt (nem jogász szakos hallgatók számára), tartózkodtak a jogi szabályok szó szerinti átvételétől, és ezzel együtt az egyes törvényhelyek számának megjelölésétől. (T. É.)

- Merre tart a magyar civilisztikai jogalkotás a XXI. század elején?

Csöndes Mónika - Nemessányi Zoltán (szerk.)

A Pécsi Tudományegyetem Állam- és Jogtudományi Kar kiadványa, Kódex, Pécs, 2010.

Tanulmánykötet. Terjedelem: 261. Bibliográfia a lábjegyzetekben. ISBN 978963 6423308.

- A szerzők fiatal generációhoz tartozó egyetemi oktatók, PhD-hallgatók, valamint gyakorlati szakemberek. A kötet a magánjogot oktatók 2009. évi, Pécsett megrendezett konferenciáján elhangzott előadások írásos változatát tartalmazza. A tanulmányok a családjog, a polgári jog és társasági jog, valamint a polgári eljárásjog köré csoportosulnak. A könyv témaválasztását a magyar civilisztikában a 21. század első évtizede második felében megjelenő jogalkotási termékek indokolták, így elsősorban az új Polgári Törvénykönyv tervezete, a Polgári perrendtartás 2008. évi novellája, valamint a módosításáról szóló 2009. évi tervezet. A kötet angol nyelvü tartalomjegyzékkel zárul. (T. É.)

- Az orvos kártérítési felelőssége

Dósa Ágnes

2., átdolgozott, bővített kiadás, HVG-ORAC, Budapest, 2010.

Monográfia. Terjedelem: 390. Bibliográfia: 382-390. és a lábjegyzetekben. ISBN 9789632581101.

- A szerző a Semmelweis Egyetem oktatója, igazságügyi orvosszakértő. A könyv a hazai bírói gyakorlat áttekintése alapján összefoglalja azokat a változásokat, amelyek az egészségügyi kártérítési eljárásokkal kapcsolatban végbementek az elmúlt években. Témakörönként elemez több száz tipikus tényállást - mint például az idegen test testüregben hagyása, szerv- és szövetátültetés, diagnosztikai tévedés - és a kialakult bírói gyakorlatot, hangsúlyosan kezelve a kárfelelősség egyes 
elemeinek az értékelését (jogellenes magatartás, kár, felróhatóság, okozati öszszefüggés). Kiemelt figyelmet szán azokra az esetekre, amelyekben a károsult arra hivatkozik, hogy a kezelést megelőzően nem kapott megfelelő tájékoztatást a beavatkozásnak az elvárható gondosság ellenére is fennálló veszélyeiről. Számadatokkal igazolja a témakör egyre fokozódó jelentőségét, és rámutat a bírói gyakorlat szerepére: egy-egy kérdés megítélése a meglehetősen tág bírói mozgástér miatt viszonylag változatlan jogszabályi környezet ellenére is egészen új irányt tudott venni. A könyvben a magyar mellett a német, osztrák, amerikai megoldások is megjelennek. (B. L.)

- Gazdasági társaságok átalakulása a gyakorlatban: a kedvezményezett átalakulás elönyei

EgRI István Iván - PÁLESNÉ Retezi Katalin

Vezinfó, Budapest, 2010.

(Sorozat: Vezinfó-tudástár, ISSN: 2061-4780)

Kézikönyv. Terjedelem: 100. Bibliográfia nincs. ISBN 9789638823793.

- A szerzők bejegyzett könyvvizsgálók és adószakértők. Szakkönyvük célja, hogy az átalakulás jogszabályi hátteréből kiindulva a folyamatban érintett szakemberek (menedzsment, ügyvéd, könyvelö, könyvvizsgáló) teendőit idörendi sorrendben bemutassa. A könyv gyakorlatiasan - példák, esettanulmányok útján - nyújtja azokat az információkat, melyek az átalakulás során jelentkező problémák megoldásához szükségesek. Mivel a sikeres átalakulás komplex ismeretanyagot feltételez, ezért a folyamat számviteli és adójogi aspektusait is bemutatja. A kiadvány szerzői külön hangsúlyt helyeztek arra, hogy felhívják a figyelmet az átalakulással járó, tipikus adókockázatokra. (B. L.)

- Társasági jogi alapismeretek: Munkaügyi és társadalombiztositási igazgatási alapszakos hallgatók részére

FARKAS Csaba

2F Iskola, Szeged, 2010.

Jegyzet. Terjedelem: 151. Bibliográfia: 151. ISBN 9789630805704.

- A szerző egyetemi oktató. Múvében tömören foglalja össze azokat az alapvető társasági jogi normákat, melyek ismerete a címben jelzett hallgatók számára szükséges. A történeti előzmények felvázolását követően ismerteti a társas vállalkozási formák alapításának, működésének és megszünésének a legfontosabb szabályait. Az általános részt követően bemutatja az egyes gazdasági társaságokra vonatkozó különös szabályokat, valamint az egyesülést és az európai részvénytársaságot. Bemutatásra kerülnek a közös vállalat (amelyet a jegyzet írásakor már nem lehetett ugyan alapítani, de a meglévők még müködhettek) jellemzői is; továbbá az egyéni vállalkozó és az egyéni cég is. A tananyag elsajátítását az egyes témakörök végén elhelyezett ellenőrző kérdések segítik. (B. L.) 
- A polgári jog felelősségi útjai vegyes jogrendszerben. Québec, Kanada FugLINSZKY Ádám

ELTE Eötvös Kiadó, Budapest, 2010.

Monográfia. Terjedelem: 518. Bibliográfia: 431-443. ISBN 9789633120248.

- A szerző ügyvéd, egyetemi oktató. Könyvében a vegyes jogrendszerek tanulmányozása során az egyes jogintézmények között kialakuló kölcsönhatásokkal foglalkozik. A magyar jogrendszerben alkalmazott megoldások kritikus szemléletű felülvizsgálatát is elvégzi; nem csupán a jelenlegi szabályozásra vonatkozó észrevételeket közöl, hanem alternatívákat is kínál, a nemzetközi szintű jogegységesítési törekvések ismertetésével. A polgári jogi felelősség útvesztőin keresztül rávilágít arra, hogy a magyar jogrendszer is a vegyes rendszerekhez közelít, ami az Európai Unión belüli jogközelítési törekvéseknek és a magyar polgári jog rekodifikációjának az eredménye. (T. I. Á.)

- Összehasonlító szerződési jog

Graziano, Thomas Kadner - Bóka János

CompLex, Budapest, 2010.

Tankönyv. Terjedelem: 602. Bibliográfia az esettanulmányok végén. ISBN 978963 2950969.

- Th. K. Graziano a Genfi Egyetem tanára; könyvét Bóka János, a Szegedi Tudományegyetem oktatója fordította le magyarra, illetve egészítette ki magyar vonatkozású részekkel. A bevezetést a szerződés létrejöttéhez, teljesítéséhez, valamint a határokon átnyúló szerződésekre alkalmazandó joghoz, továbbá az európai szerződési joghoz kapcsolódó esettanulmányok követik. A munka ezáltal rávilágít a szerződési jog legfontosabb intézményeire és a kapcsolódó jogterületek alapproblémáira. Az egyes tanulmányok jogesetekből kiindulva jogszabályhelyek, bírósági ítéletek és jogtudományi írások alapján hasonlítják össze az egyes jogrendszerek megoldásait és a legjelentősebb jogharmonizációs kísérleteket. A könyv elsődleges célja az összehasonlító jog alapjainak megismertetése a joghallgatókkal. Az áttekintő táblázatok hallgatóbaráttá teszik a könyvet. (T. É.)

- Az élettársi kapcsolat a polgári jogi kodifikáció tükrében

Hegedüs Andrea

Pólay E. Alapítvány, Szeged 2010.

Monográfia. Terjedelem: 174. Bibliográfia: 165-171. ISBN 9789639650732.

- A szerző egyetemi oktató, munkájának időszerüségét adja, hogy korábban teljesen hiányzott az élettársi kapcsolatra vonatkozó átfogó jogi szabályozás, s a téma szakértői a meglévő, hiányos szabályokra támaszkodva, legfeljebb alternatívákat állíthattak fel a szabályozás kialakítása érdekében, segítve a kodifikáció folyamatát. A történeti és demográfiai összefüggéseiben bemutatott, hatályos szabályozás mellett ismertetésre kerülnek a külföldi (pl. holland, skandináv, brit) megoldások jellegzetességei. A szerző rámutat arra is, hogy a nemzetközi egyezmények és az Európai Unió hogyan ítélik meg az élettársi kapcsolat mint társadalmi és egyben jogintézmény szerepét. (T. I. Á.) 
- Nemzetközi választottbíráskodás

HoRVÁth Éva

HVG-ORAC Lap- és Könyvkiadó Kft., Budapest, 2010.

Kézikönyv. Terjedelem: 299. Bibliográfia: 287-291. ISBN 9789632581002.

- A könyv fö témája az 1994. évi LXXI. törvény létrejötte és az azon alapuló választottbírósági gyakorlat. A nemzetközi jogi környezet felvázolását követően bemutatja azt a folyamatot, amelynek során az ENSZ Nemzetközi Kereskedelmi Jogi Bizottsága által kidolgozott szabályozási megoldás (a szabályozás harmonizálását célzó „mintatörvény”) hazai adaptációja megtörtént. Ennek értékelésekor külföldi példákra is támaszkodik. Gyakorlatias megközelítéssel elemzi a Magyar Kereskedelmi és Iparkamara mellett szervezett választottbíróság eljárási szabályzatát, bemutatja a Világkereskedelmi Szervezet vitarendezési eljárását, illetve az alternatív vitarendezési eljárásokat is. A legfontosabb nemzetközi dokumentumokat angol nyelven közli. (T. I. Á.)

- Személyi és családi jog

JoBBÁGYı Gábor

Szent István Társulat, Budapest, 2010.

(Sorozat: A Pázmány Péter Katolikus Egyetem Jog- és Államtudományi Karának könyvei, ISSN 1417-7285)

Tankönyv. Terjedelem: 350. Bibliográfia: a fejezetek végén. ISBN 978963361 6574.

- A szerző egyetemi oktató. A tankönyv a polgári jogi oktatásban újszerú megközelítést érvényesít: a Ptk.-hoz képest (pl. a Ptk.-n kívüli jogi személyekkel) jelentősen kibővítve tárgyalja a személyi jogot, és számos olyan, gyakorlati relevanciával bíró jogterületet érint, mely a polgári jog részét képezi. Hangsúlyos az ember mint jogalany polgári jogi védelméről szóló rész, emellett azonban a jogi személyhez kapcsolódó problémákat is áttekinti a szerző, a hagyományoshoz képest új alapokon. A családi jogot a polgári jog viszonylag önálló részeként kezeli; a korábbi, leegyszerűsítő „bontójogi” megközelítésen túllépve a házassági viszony egyéb aspektusait is azonos súllyal mutatva be. Magát a házasságot a két fél szerződésének tekinti, és ezt szem előtt tartva ismerteti a vonatkozó szabályozást. Ez a szemlélet idővel uralkodóvá is válhat, a Ptk.-kodifikáció eredményeképpen. (T. É.)

- Kötelmi jog

JoBbÁGYI Gábor - FAZEKAS Judit

Szent István Társulat, Budapest, 2010.

(Sorozat: A Pázmány Péter Katolikus Egyetem Jog- és Államtudományi Karának könyvei, ISSN 1417-7285)

Tankönyv. Terjedelem: 395. Bibliográfia: 140-142., 194-195., 393-394. ISBN 978 9633619681.

- A szerzők egyetemi oktatók. A munka elsősorban a jogi oktatás célját szolgálja. A kötelmi jog a polgári jog oktatásában kiemelten hangsúlyos terület. A gyakorlattól eltérve a szerzők egy mübe foglalták össze a kötelmi jog általános részét és a 
szerződések jogát, azonban az egyes fejezetek belső felépítése nem mutat jelentős eltérést az e tárgykörben született más tankönyvekhez képest. (T. É.)

\section{- A magyar fizetésképtelenségi jog kézikönyve}

JuHÁsz László

[2. kiadás] Novotni, Miskolc, 2010.

Kézikönyv. Terjedelem: 960. Bibliográfia: 896-897. ISBN 9789639360716.

- A szerző nyugalmazott bíró, egyetemi oktató. A kézikönyv 2006-os kiadásához képest jelentős változások következtek be e jogterületen, köszönhetően a 2009. évi LI. törvény megjelenésének, illetve az azt követő számos, kisebb módosításnak. A csődeljárás szabályainak a felülvizsgálatában nem kis szerepet játszott a 2008ban kezdődött gazdasági válság. A jogalkalmazók számára nehézséget jelentett a gyakori változtatás, amely gyakran még azt sem várta be, hogy kialakuljon az előző törvényi rendezés gyakorlata. A kézikönyv számukra kínál segítséget, amenynyiben a 2010 januárjában hatályos joganyag első értékelését, illetve megoldáscentrikus értelmezését adja. Részletes tartalomjegyzék és mellékletek segítik a használatát. (B. L.)

\section{- Az alanyi jog funkcionális elmélete}

KAUSER Lipót; Csöndes Mónika (szerk.)

Pécsi Tudományegyetem Állam- és Jogtudományi Kar, Pécs, 2010.

Monográfia. Terjedelem: 255. Bibliográfia: 219-220. és a lábjegyzetekben. ISBN 9789636423452.

- A mü középpontjában Kauser Lipót (1882-1962), a Pécsi Tudományegyetem egykori neves jogprofesszora 1956-ban készített és 1959-ben megvédett, máig kiadatlan kandidátusi értekezése áll. A szerző nem fogadta el az alanyi jog fogalmára vonatkozó addigi elméleteket (érdekelmélet, akaratelmélet, facultas agendi elmélet, vegyes elméletek), hanem megkísérelte induktív úton, különböző jogi valóságok sorozatából, tagok konstans elemeiböl, absztraktív általánosítással saját maga definiálni az alanyi jog mibenlétét. A szerkesztő eredeti formájában teszi közzé az értekezést, kiegészítve Csanádi György és Névai László opponensi véleményével és az ezekre adott válasszal. Ismerteti Kauser életútját és életművét is. (B. L.)

- A gazdasági szféra alanyai - gazdasági társaságok

Károlyı Géza - Fézer Tamás - PetKó Mihály - Törö Emese

4., átdolgozott kiadás. Debreceni Egyetemi Kiadó, Debrecen, 2010.

Tankönyv. Terjedelem: 288. Bibliográfia: 287-288. ISBN 9789634733775.

- A szerzők a Debreceni Egyetem oktatói; munkájuk elsősorban jogi oktatási célokat szolgál. Teljes körüen feldolgozza a gazdasági élet szereplőire vonatkozó joganyagot. A gazdasági társaságok mellett a gazdasági élet valamennyi jelentős résztvevője - mint például az egyéni vállalkozó vagy a mezőgazdasági őstermelő - is kifejtésre kerül. A tankönyv kitekint az Európai Unió társasági jogot érintő jogalkotási tendenciáira, illetve fontosabb „vívmányaira”, az EU-jog égisze alatt müködő szupranacionális szervezetekre is. Tudatosan nem foglalkozik a gazdasági 
társaságok megszünésének létszakaszával, amit a szerzők külön jegyzetben dolgoztak fel. (B. L.)

\section{- Magyar polgári eljárásjog}

Kengyel Miklós

10. kiadás. Osiris, Budapest, 2010.

Tankönyv. Terjedelem: 653. Bibliográfia fejezetenként. ISBN 9789632761770.

- A szerző egyetemi oktató, kötete a magyar polgári eljárásjog oktatásának egyik alapmúve. Az első fejezetekben bemutatja a polgári eljárásjog alapfogalmait, jogforrásait és fejlődéstörténetét, valamint alapvető elveit, majd a bírósági szervezetet. Ezután a polgári perrendtartás rendszerét követve részletesen foglalkozik az elsőfokú eljárással, a polgári per szerkezetével, az első- és másodfokú eljárással, a perorvoslatokkal és a különleges perekkel. A nemperes eljárások között külön is feldolgozza a 2010-re új szabályanyagot kapott fizetési meghagyásos eljárást, de emellett hasonló részletességgel mutat be más nemperes eljárásokat is. A teljesség jegyében a zárófejezetek tartalmazzák a mediációval, illetve választott bíráskodással kapcsolatos anyagot is. A címlapon a Debreceni Törvényszék egyik tárgyalótermének a képe látható. (Á. Zs.)

- Kártéritési jog

KöHIDI Ákos

UNIVERSITAS - GYőR Nonprofit Kft, Győr, 2010. Jegyzet. Terjedelem: 105. Bibliográfia: 103-105. ISBN 9789639819566.

- A szerző egyetem oktató, könyvében a polgári jogi felelősséggel, a magánjog legtöbbet vitatott és legnagyobb érdeklődésre számot tartó területével foglalkozik. A kártérítési jog egyes sarokpontjainak a megvilágításához ötvözi az elméleti és gyakorlati szempontokat. A felelősségtan körében felmerülő problémákat valós és érdekes jogesetek megoldása útján válaszolja meg, mindeközben rámutat különböző szabályozási és jogalkalmazási dilemmákra. Több esetben kitekint külföldi megoldásokra, elméleti irányzatokra is. Foglalkozik az általános és speciális kárfelelősségi alakzatokkal, a nem vagyoni kártérítéssel, s idekapcsolódó kérdéseket feszeget - a Ptk.-n túlról - a szerzői jog és a fogyasztóvédelmi jog körében. (B. L.)

- A gazdasági jog szabályozás I-II.

NocHTA Tibor - JuHÁsz László - SzécséNYı László

Dialóg Campus, Budapest-Pécs, 2010.

(Sorozat: Jogi szakvizsga segédkönyvek, ISSN 1587-6659, Dialóg Campus szakkönyvek, ISSN 1417-7986.)

Tananyag. Terjedelem: 247 (I. kötet) és 280 (II. kötet). Bibliográfia nincs. ISBN 978 963729633 8; 9789637296086.

- A szerzők egyetemi oktatók, illetve gyakorlati szakemberek. Könyvük elsősorban a jogi szakvizsga gazdasági jogi moduljára történő sikeres felkészülést segíti, két részben. A kötetek tartalma igazodik a jogi szakvizsgára vonatkozóan az igazságügyi tárca által kiadott követelményekhez. Az I. kötet a téma alapvetését követően 
(elsősorban a Gt. alapján) a gazdasági társaságokra vonatkozó közös rendelkezéseket, valamint az egyes típusok speciális szabályait, illetve az egyéni vállalkozóra és egyéni cégre vonatkozó joganyagot tartalmazza. A II. kötet taglalja a cégjogra, a csőd- és felszámolási eljárásra, az értékpapír-forgalomra, valamint a versenyjogra, közbeszerzési jogra és szövetkezetre vonatkozó szabályokat. (B. L.)

\section{- Társasági jog}

NochTA Tibor

2., átdolgozott, bővített kiadás. Dialóg Campus, Budapest-Pécs, 2011.

(Sorozat: Dialóg Campus tankönyvek, ISSN 1418-1274, Institutiones juris, ISSN 1218-9375.)

Monográfia/Tankönyv. Terjedelem: 382. Bibliográfia: 381-382. ISBN 9789639950 344.

- A szerző egyetemi oktató, a Magyar Kereskedelmi Kamara mellett szervezett Állandó Választottbíróság tagja. Tankönyve tematikus rendben tárgyalja a társasági jog fő kérdéseit, és feldolgozza a társasági jogot érintő, a 2007-es első kiadás óta bekövetkezett, jelentős változásokat. Mindamellett, hogy hosszan részletezi a társasági törvényt és a társasági jog más jogágakkal, jogterületekkel való kapcsolódását, megismerteti az olvasót a társas vállalkozások jogának intézménytörténeti kialakulásával is. (B. L.)

- A szerzői jogi ágazatok gazdasági súlya Magyarországon

PenYigel Krisztina

MSZH, Budapest, 2010.

Kézikönyv. Terjedelem: 81. Bibliográfia: 69-71. és a jegyzetekben. ISBN 978963 9157644.

- A füzet a Magyar Szabadalmi Hivatal felmérésének eredményeit mutatja be, mely felmérés a kreatív ágazatok gazdasági teljesítményét, foglalkoztatási mutatóit és ezek változását kutatta. 2006-os adatokkal dolgozott, és azokat nemzetközi öszszehasonlításban (más tagállamokat is megkeresve hasonló felmérések lefolytatása érdekében), valamint más nemzetgazdasági ágazatokkal összevetve, a külkereskedelmi forgalmat is tekintetbe véve elemezte. Kimutatta, hogy a szerzői jogi szektor makrogazdasági súlya kimagaslóan magas mindkét összehasonlításban. A kötet további részeiben a kulturális ágazatok fejlődési tendenciái és a szerzői jogi szabályozás változása is górcső alá kerül. (T. É.)

- Bírósági végrehajtás

Pestovics llona

3. kiadás. Novissima, Budapest, 2010.

(Sorozat: Jogi szakvizsga kézikönyvek, ISSN 1786-0806)

Kézikönyv. Terjedelem: 329. Bibliográfia nincs. ISBN 9789639403385.

- A szerző gyakorló bíró. A kötettel elsősorban a jogi szakvizsgára készülőknek kíván segítséget nyújtani. A könyv a bírósági végrehajtásról szóló 1994. évi LIII. törvény I-XV. fejezete mellett számos más, magyar és európai uniós jogszabály alapján 
készült, és a vonatkozó polgári kollégiumi véleményeket is tartalmazza. A szerző a hatályos joganyag mellett a gyakorlatra is figyelmet fordított, és szól a külföldi határozatok elismeréséről is. A kötet a 2010. augusztus 1-jén hatályos joganyagot tartalmazza. (L. N.)

- A magánjogi kodifikáció eredményei

Pusztahelyi Réka (szerk.)

Novotni, Miskolc, 2010.

Tanulmánykötet. Terjedelem: 168. Bibliográfia a jegyzetekben. ISBN 9789639360 730.

- A szerzők bírák, illetve egyetemi oktatók az ország különböző intézményeiből. 2009 júniusában 15. alkalommal rendezték meg a Miskolci Egyetem Állam- és Jogtudományi Kar Polgári Jogi és Kereskedelmi Jogi Tanszékei a Polgári Jogot Oktatók Országos Talákozóját (POT-konferenciát). Az ott elhangzott előadások szerkesztett anyagát, valamint egy külön tanulmány keretében a konferencia hozzászólásait tartalmazza a kötet. A 2009-es találkozó és így a kiadvány választott témája a szerződés érvénytelensége, figyelemmel arra, hogy a tárgyévben ennek a jogintézménynek az egyes gyakorlati vonatkozásai a bírói testület elött is kiemelt kérdésként szerepeltek. (T. É.)

- A gazdálkodó szervezetek végelszámolásáról

RENKó Ferenc István - LADÁNYI Gábor

Saldo, Budapest, 2010.

(Sorozat: Röviden szólva... ISSN 1587-1363.)

Kézikönyv. Terjedelem: 80. Bibliográfia nincs. ISBN 9789636383398.

- A szerzők gyakorlati szakemberek, az APEH KAIG vezető főtanácsosai. Céljuk azt elősegíteni, hogy a végelszámolás útján megszűnni kívánó gazdálkodó szervezetek jobban megismerhessék az eljárás egyes lépéseit, és problémamentesen fejezhessék be müködésüket. A könyv a végelszámolás lépcsőit az eljárás során felmerülő számviteli és adóbevallási feladatokkal együtt ismerteti. Jelentős gyakorlati segítséget nyújt azáltal is, hogy összegyűjti és megválaszolja a folyamat során a leggyakrabban felmerülö kérdéseket. (B. L.)

- Előadásvázlatok a személyek jogából

SÁNDOR István

Patrocinium, Budapest, 2010.

(Sorozat: Bethlen-sorozat, ISSN 2062-2546)

Oktatási segédanyag. Terjedelem: 190. Bibliográfia: 184-189. ISBN 9789638905 185.

- A szerző egyetemi oktató, a kötet saját egyetemi előadásvázlatait tartalmazza, melyeket több év oktatói gyakorlatából válogatott össze a személyek joga tárgyában. Sorra veszi a személyek jogának legfőbb szegmenseit, így bemutatja a természetes személyek, a jogi személyek és az utolsó fejezetben a személyhez füződő jogok tárgykörét. A fent említett témák részletes kifejtése mellett megjelennek az aktuális tendenciák és az európai uniós szabályozás is. (T. É.) 
- Emlékkönyv Apáthy István tiszteletére

Szabó Marcel (szerk.)

Európa Nostra, Budapest, 2010.

Tanulmánykötet. Terjedelem: 204. Bibliográfia nincs. ISBN 978963891591.

- A kötet megjelenésének apropója Apáthy István születésének 180. és halálának 120. évfordulója volt, melyet 2009-ben ünnepelt a jogászság. A szerzők a Pázmány Péter Katolikus Egyetem oktatói, azé az egyetemé, melynek egykor Apáthy a rektora volt. A tanulmányok egy része polgári jogi, másik része nemzetközi jogi tárgyú. Ez a kettősség Apáthy pályafutásával állítható párhuzamba, akinek a kiemelkedő magánjogi munkássága mellett a nemzetközi jog területén kifejtett tevékenysége is maradandónak bizonyult. Jelen tanulmánygyüjtemény különböző témájú írásokat tartalmaz, így olvashatunk többek között a szerzői alkotások védelméről (Apáthy székfoglalójának tanulságain elmélkedve), az orvosok kártérítési felelősségéröl; a nemzetközi jogi rovatban szereplö tanulmányok közül pedig több is foglalkozik az emberi jogok érvényesülésének egyes kérdéseivel. (T. É.)

- A közterületi parkolás jogi szabályozása - tisztességtelen jogalkotás?

SZÉCsÉNYI-NAGY Kristóf

MTA Jogtudományi Intézet, Budapest, 2010.

(Sorozat: Magyar Tudományos Akadémia Jogtudományi Intézete, Közlemények; 24.)

Tanulmány. Terjedelem: 82. Bibliográfia a lábjegyzetekben. ISBN 9789637311 628.

- A szerző egyetemi oktató. Munkája a parkolási jogviszonyt elsősorban magánjogi oldalról vizsgálja, s arra keresi a választ, hogy alkalmas-e a magánjog az e jogviszonnyal összefüggő jogviták kezelésére, van-e alkalmas szankciója a represszióra, s egyáltalán, beilleszthető-e a parkolási jogviszony a magánjog rendszerébe. Mivel a főváros rendelkezik a legtöbb díjfizetési kötelezettséggel érintett közterületi parkolóhellyel, s itt a legjelentősebb a gépjármüforgalom is, így a Fővárosi Közgyülés által alkotott rendeleteken keresztül mutatja be a szabályozást, amit nemzetközi kitekintéssel is kiegészít. (T. A. N.)

- Magyar fogyasztóvédelmi magánjog - európai kitekintéssel

Szikora Veronika (szerk.)

A Fogyasztóvédők Magyarországi Egyesületének (FOME) kiadványa. Center Print, Debrecen, 2010.

Tankönyv. Terjedelem: 388. Bibliográfia fejezetenként. ISBN 9786155025006.

- A szerzők egyetemi oktatók, illetve gyakorlati szakemberek. A könyv a fogyasztóvédelmi magánjogi viszonyokra és a fogyasztóvédelem alapvető intézményeire koncentrálva a hazai és európai előzményeket, valamint a joggyakorlatot dolgozza fel. Tematikája és felépítése a FOME által végzett oktatási tevékenység igényeihez igazodik, és a Debreceni Egyetem Állam- és Jogtudományi Karán folyó fogyasztóvédelmi kutatás eredményeire támaszkodik. Ennek megfelelően nemcsak tananyagként, hanem kézikönyvként is használható. (T. É.) 
- A polgári nemperes eljárások joga

Varga István (szerk.)

ELTE Eötvös Kiadó, Budapest, 2010.

(Sorozat: ELTE jogi kari tankönyvek, ISSN 2060-6494; 2.)

Tankönyv/Kézikönyv. Terjedelem: 1147. Bibliográfia a lábjegyzetekben. ISBN 978 9632841168.

- A szerzők egyetemi oktatók és gyakorló jogászok. A könyv nem kizárólag nemperes eljárásokat tárgyal, hanem olyan peres eljárásokat is, amelyek lényegüket a nemperes eljárásokkal összefüggésben nyerik el. A polgári nemperes eljárások fogalmának meghatározását és általános jellemzését követően részletesen ismerteti a bírósági végrehajtást, a cégeljárásokat, a fizetésképtelenségi eljárásokat, a hagyatéki és egyéb közjegyzői nemperes eljárásokat, illetőleg olyan egyéb fontosabb bírósági eljárásokat, mint a holtnak nyilvánítás, a halál tényének bírósági megállapítása, közigazgatási nemperes eljárások. (B. L.)

- Magyar polgári jog - Öröklési jog

VÉKÁs Lajos

6., javított kiadás, Eötvös József Könyvkiadó, Budapest, 2010.

Tankönyv. Terjedelem: 142. Bibliográfia az egyes részek végén. ISBN 978963 9955172.

- A szerző egyetemi oktató, az MTA rendes tagja. A tankönyv témája az öröklési jog, mely a magántulajdon szentségére épülő társadalmi rendekben kiemelt jelentőséggel bír. Elsősorban a jogi oktatás céljait szolgálja, s ehhez az öröklési jog fogalmait (mint az öröklés, hagyaték, kötelesrész), rendjét és intézményeit tárgyalja, ismertetve a legfontosabb bírói döntéseket, illetve a jogalkalmazás során felmerülő problémákat is. Az öröklési rend bemutatását számos szemléltető ábra kíséri. (B. L.)

- Polgári eljárásjog. Tankönyv alapképzésben (Ba) és jogi asszisztens képzésben résztvevők számára

Wopera Zsuzsa

Novotni, Miskolc, 2010.

Egyetemi jegyzet. Terjedelem: 218. Bibliográfia nincs. ISBN 9639360147.

- A szerző egyetemi oktató. Jegyzete a különféle igazgatási (elsősorban az igazságügyi ügyintéző) alapszakok hallgatóinak készült a polgári eljárásjogi ismeretek elsajátításának megkönnyítésére. Tizenöt fejezetben tekinti át a polgári eljárásjogi alapismereteket. A tantervi követelményekre tekintettel egy-egy perjogi jogintézmény kapcsán számos esetben részletesen kitér a polgári anyagi jogi háttérszabályokra is. A tananyag elsajátítását az átlátható tagolás, a felsorolások és a dőlt betüs kiemelések segítik. (F. F.)

- Az igazságszolgáltatás szervezete és ügyviteli szabályai. Tankönyv jogi asszisztens képzésben résztvevök számára

Wopera Zsuzsa - Nagy Adrienn (szerk.)

Novotni, Miskolc, 2010. 
Egyetemi jegyzet. Terjedelem: 376. Bibliográfia nincs. ISBN 9789639360709.

- A szerzők egyetemi oktatók. Jegyzetük a jogiasszisztens-képzés hallgatói számára, az igazságügyi ügyviteli kurzus tananyagának segédleteként készült. Ennek megfelelően a kötet áttekinti a bírósági és ügyészségi szervezetrendszert és feladatokat, a bírósági és ügyészségi ügyvitel folyamatát, a közjegyzői és ügyvédi adminisztrációs feladatokat. (F. F.)

\section{KÖZIGAZGATÁSI JOG ÉS PÉNZÜGYI JOG}

- Hódmezővásárhely törvényhatósága (1919-1944). Fejezetek a magyar városigazgatás történetéből

ANTAL Tamás

Csongrád Megyei Levéltár, Szeged, 2010.

(Sorozat: Dél-alföldi Évszázadok, ISSN 0237-4587; 27.)

Monográfia. Terjedelem: 258. Bibliográfia: 151-161. és a lábjegyzetekben. ISBN 9789637237768.

- A szerző egyetemi oktató; a két világháború közötti történelmi periódus városfejlődését vizsgálja. Munkája túlmutat a településtörténeti vizsgálaton: Hódmezővásárhely törvényhatósági jogú város 1919-1944. közötti közigazgatásán keresztül bemutatja az időszak közigazgatási intézményeit, azok egymásra torlódását és fejlődését. Így képet kapunk a közjogi provizórium időszakáról, a közigazgatás rendezésének lépéseiről és a városok helyzetéről. A munkát a korszak archontológiája, a hivatkozott jogszabályok jegyzéke, személy- és helynévmutató, illetve forrásjegyzék zárja. (B. A.)

- Az épitési beruházás folyamata: az építési beruházás engedélyei

Babus Júlia - Hegedüs Annamária - KuRucz Mihály

Complex, Budapest, 2010.

(Sorozat: Építésügyi Kiskönyvtár, ISSN 2061-8549; 4.)

Kézikönyv. Terjedelem: 566. Bibliográfia nincs. ISBN 9789632950532.

- A szerzők építésügyi szakemberek, illetve egyetemi oktatók. A kötetből megtudhatjuk, milyen típusú engedélyek megszerzése szükséges egy építési beruházás kivitelezésének megkezdéséhez, azok mennyi időt vesznek igénybe, és mely hatóságoktól kell ezeket az engedélyeket beszerezni. A kötet részletesen bemutatja az építésügyi hatósági eljárásokat, azok valamennyi alapvető intézményével együtt, külön részletezi a hatósági engedélyezési eljárásokat, az ellenőrzésre és bejelentésre vonatkozó elöirásokat. Kitér a műemlékvédelem, illetve egyes sajátos építményfajták engedélyezési eljárásaira és a földvédelemmel kapcsolatos kérdésekre is. (B. A.)

- A települési önkormányzatok stratégiai vezetése

BÁRdiné Metzker Erika - Csuth Sándor

Települési Önkormányzatok Országos Szövetsége, Budapest, 2010.

Tanulmány. Terjedelem: 88. Bibliográfia: 88. ISBN 9789638906830. 
- A szerzők közigazgatás-szervezési szakemberek. Tanulmányukban arra keresik a választ, hogy milyen a ,jó önkormányzat”, és ez miképpen valósítható meg. A ,jó” önkormányzás egyik eszköze a tanulmányban részletesen vizsgált stratégiai vezetés, amely az elemző gondolkodás, az akciók tervezése és az akciók végrehajtásához szükséges erőforrások rendelkezésre bocsátása révén valósitható meg. (B. A.)

- Pályázati ismeretek és közbeszerzés

Boros Anita - HutKAI Zsuzsanna - TÁtral Tünde

Települési Önkormányzatok Országos Szövetsége, Budapest, 2010.

(Sorozat: Polgármester Akadémia; 7.)

Kézikönyv. Terjedelem: 104. Bibliográfia: 50-51. és 103. ISBN 9789638906861.

- A szerzők egyetemi oktatók, kutatók. A kézikönyv elsősorban a polgármesterek számára kíván hasznos ismereteket nyújtani a pályázatokkal és közbeszerzésekkel kapcsolatban. Az első rész a pályázás egyes szakaszaihoz igazodva dolgozza fel az önkormányzatok számára nyitva álló pályázati lehetőségek mellett a projektek megtervezésének és megvalósításának lépéseit. A második rész a közbeszerzési eljárás alapvető intézményeit mutatja be. Az ismeretek feldolgozását ábrák, kimutatások és önellenőrző kérdések segítik. (B. A.)

\section{- Államháztartástan}

Botos Katalin - SCHLETT András

2., átdolgozott kiadás. Szent István Társulat, Budapest, 2010.

Egyetemi jegyzet. Terjedelem: 149. Bibliográfia az egyes fejezetek végén. ISBN 9789633615843.

- A szerzők egyetemi oktatók. A kötet a PPKE JÁK Heller Farkas Közgazdaságtudományi Intézetében készült jegyzet, amelyet a szerzők a joghallgatók közgazdaság-tudományi stúdiumaihoz szántak. A kötet az államháztartás-tani ismereteket kilenc fejezetben tekinti át, így külön fejezetben foglalkozik többek között a központi költségvetés bevételeivel, kiadásaival, egyes alrendszereivel, illetve a költségvetési egyenleg és az uniós költségvetés témaköreivel. A kötet végén a fontosabb fogalmak jegyzéke, az egyes fejezetek végén ismétlő kérdések segítik az ismeretek elsajátítását. (F. F.)

- Magyar pénz- és tőkepiaci rendszer

Botos Katalin - Bódy László

7., átdolgozott kiadás. Szent István Társulat, Budapest, 2010.

Egyetemi jegyzet. Terjedelem: 151. Bibliográfia az egyes fejezetek végén. ISBN 9789632771809.

- A szerzők egyetemi oktatók. A kötet a PPKE JÁK Heller Farkas Közgazdaságtudományi Intézetében készült jegyzet, amelyet a szerzők a joghallgatók közgazdaság-tudományi stúdiumaihoz szántak. A kötet nyolc fejezetben tekinti át a magyar bankrendszer szintjeit, a hitelintézetek biztonságos működésének szabályozását, a bankműveleteket és a biztosítási és értékpapírpiac sajátosságait. Az egyes fejezetek végén önellenőrző kérdések segítik a tananyag feldolgozását. ( $F$. $F$.) 
- Pénzügyi jogot oktatók konferenciáinak elöadásai: a 2006. november 30-án a Miskolci Egyetem Állam- és Jogtudományi Karán megtartott konferencia előadásai Erdős Éva (szerk.)

Novotni, Miskolc, 2010.

Konferenciakötet. Terjedelem: 272. Bibliográfia az egyes fejezetek végén. ISBN 9789639360747.

- A tanulmányok szerzői hazai és külföldi egyetemi oktatók a pénzügyi jog, illetve a kereskedelmi jog területén. A kötet a 2006-ban a Miskolci Egyetemen a „Pénzügyi jog az európai jogfejlődés útján" címmel rendezett pénzügyi jogi konferencia szerkesztett anyagát tartalmazza. A feldolgozott témák között egyaránt megtaláljuk a hazai adójogi és bankrendszert, értékpapírjogot, illetve társadalombiztosítást érintő kérdéseket, illetve az Alkotmánybíróság és az Európai Unió Bírósága pénzügyi tárgyú döntéseinek áttekintését. (Á. Zs.)

- Az önkormányzati rendeletek szerkesztése a 61/2009. (XII. 14.) IRM rendelet alapulvételével

GeLENCSÉr József

Közigazgatás Módszertani Bt., Pécs, 2010.

(Sorozat: Közigazgatás a gyakorlatban, ISSN 1218-8018; 37.; „Jegyzök dokumentumtára", ISSN 1219-9222; 36.)

Kézikönyv. Terjedelem: 236. Bibliográfia nincs. ISBN 9789638696564.

- A szerző közigazgatási jogász. A kötet az 1987-es jogalkotási törvényhez kapcsolódó, a jogszabályszerkesztést szabályozó miniszteri rendelet alkalmazásával foglalkozik, speciálisan az önkormányzati rendeletekkel kapcsolatban. A kötet bemutatja a jogszabály tervezetére vonatkozó általános rendelkezéseket, a jogszabály tervezetének formai és logikai tagolását, továbbá a jogszabály mellékletével kapcsolatos tudnivalókat. A logikai tagolással összefüggésben a szerző a vonatkozó rendelet szerkezetének megfelelő sorrendben ismerteti az egyes szerkezeti egységekkel kapcsolatos kritériumokat. A kötet a módosítandó és hatályon kívül helyezendő jogszabály kérdésével és a dereguláció követelményével is foglalkozik. (Á. Zs.)

- Az új adójog magyarázata, 2010

Hadi László (szerk.)

HVG-ORAC, Budapest, 2010.

Kommentár. Terjedelem: 1013. Bibliográfia nincs. ISBN 9789632580821.

- A kötet szerzői adóügyi szakemberek. Az 1996 óta szinte minden évben megjelenő kommentár a 2010. január 1-jei állapotnak megfelelően, nagy részletességgel tekinti át az adózással és az egyes adófajtákkal (áfa, társasági adó, szja, eva, eho) kapcsolatos jogszabályi rendelkezéseket. Az adózás rendjét taglaló, legterjedelmesebb részben külön fejezet foglalkozik az adózás és az adózó fogalmával, az adóhatóságok rendszerével, az adóinformációs rendszerrel, illetve az adóigazgatási eljárással. A szerzők kitérnek az egyes témakörök uniós jogi vonatkozásaira is. Az adózással kapcsolatos egyes számítások megértését a kötet példákkal segíti. (F. F.) 
- Az épitési beruházás folyamata: az építmény fenntartása, jókarbantartása, védelme

Hegedüs Annamária - Szabó Zsuzsanna

Complex, Budapest, 2010.

(Sorozat: Építésügyi Kiskönyvtár, ISSN 2061-8549; 7.)

Kézikönyv. Terjedelem: 263. Bibliográfia nincs. ISBN 9789632950563.

- A szerzők építésügyi szakértők. A kötet arra ad választ, hogy az építtetőnek, a tulajdonosnak milyen feladatai, kötelezettségei vannak, lehetnek a használatbavételi engedély megszerzését követően az építmény tekintetében. Így többek között megtudhatjuk, melyek az építményekkel szemben támasztott követelmények az épület teljes fennállása során, milyen szakértőkkel mikor kell megvizsgáltatni az építményeket, hogyan kell vezetni a szervizkönyvet, vagy mikor kell energetikai tanúsítványt készíttetni.

\section{- Az egészségügyi szolgáltatások rendszertana}

Homıcskó Árpád Olivér

KGRE ÁJK, Budapest, 2010.

(Sorozat: Jog és Állam, ISSN 1787-0607; 16.)

Kézikönyv. Terjedelem: 97. Bibliográfia: 89-97. és a lábjegyzetekben. ISBN 978 9639808249.

- A szerző egyetemi oktató, ügyvéd; az egészségügyi szolgáltatásokra vonatkozó joganyagot és a hozzá kapcsolódó alkalmazási gyakorlatot tekinti át. Kiindulópontjául a magyar lakosság egészségügyi állapota, az egészségügyi ellátás eloszlása, valamint a teherviselésben megjelenő szabályok szolgáltak, de kitér a jogi szabályozás mögött meghúzódó gazdasági folyamatokra és törvényszerüségekre is. A szervezet-, szolgáltatási és finanszírozási rendszer mellett külön vizsgálja az államnak a lakosság egészségi állapotáért fennálló felelősségét, valamint az egyes egészségügyi szolgáltatások privatizálásának lehetőségeit. (B. A.)

- Közszolgálati jogi tansegédlet: jogesetek, feladatok, iratminták, jogszabályok HoRvÁTH Attila BCE KIK, Budapest, 2010.

Tansegédlet. Terjedelem: 96. Bibliográfia nincs. ISBN nincs.

- A szerző egyetemi oktató. A tansegédlet gyakorlati feladatokkal kiegészítve foglalja össze a közszolgálatra vonatkozó legfontosabb elméleti ismereteket. Az első részben jogesetek és feladatok kaptak helyet, a másodikban iratminták, az utolsó részben pedig jogszabályok. A tansegédlet jellemzően táblázatos formában, valamint rövid esetleírásokon keresztül méri fel a hallgatók ismereteit, és vezeti rá őket a feladatok helyes megoldására. (B. A.)

- 20 év a védelmi igazgatásban 1990-2010. A Honvédelmi Minisztérium Védelmi Hivatal története keresztmetszetében Jároscsák Miklós - Kaszás Mihály (szerk.) Honvédelmi Minisztérium Védelmi Hivatala, Budapest, 2010. Kézikönyv. Terjedelem: 190. Bibliográfia nincs. ISBN 9789637037627. 
- A szerkesztők a védelmi igazgatás gyakorló szakemberei. A kiadvány 1990-től 2010. április 30-ig vázolja fel a HM Védelmi Hivatal történetét, a védelmi kötelezettségek teljesítéséhez, valamint a honvédelmi felkészítéshez kapcsolódó eseményeket. Bemutatja a rendszerváltás óta bevezetett, az új típusú védelmi igazgatást megalapozó intézkedéseket, kialakításuk lépéseit. A NATO-csatlakozástól 2010-ig ismerteti a hivatal működésének jellemzőit. A munkából megismerhető a védelmi igazgatás központi és területi-helyi szervezetrendszere mellett az általános és ágazatspecifikus tevékenységek köre is. A könyvet a hivatal és jogelőd szervezetei állományában tevékenykedő személyek nevének felsorolása zárja. (B. A.)

- 20 évesek az önkormányzatok - Születésnap, vagy halotti tor?

Kákai László (szerk.)

IDResearch Kft.-Publikon, Pécs, 2010.

Konferenciakötet. Terjedelem: 630 . Bibliográfia az egyes tanulmányok végén. ISBN 9786155001055.

- A szerzők egyetemi oktatók, kutatók, gyakorlati szakemberek. A kötet a helyi önkormányzatokat a rendszerváltás után felállító 1990. évi LXV. törvény 20. évfordulójának tiszteletére, a Pécsi Tudományegyetemen rendezett konferencia anyagának szerkesztett változatát tartalmazza. Az önkormányzati igazgatás és szervezet valamennyi szegmensét átfogó, változatos témájú tanulmányok a konferencia szekciói szerinti bontásban (európai uniós kérdések, önkormányzati szintek, önkormányzati feladatok és pénzügyek, e-közigazgatás, helyi társadalom) szerepelnek, míg a kötet első fejezete a plenáris előadásokat közli. (Á. Zs.)

- Egyetemirányitás: lehetőségek és korlátok

KeCzer Gabriella

Szeged, Egyesület Közép-Európa Kutatására, 2010.

Monográfia. Terjedelem: 156. Bibliográfia: 137-144. ISBN 9789630803076.

- A szerző föiskolai oktató, ebben a munkában doktori disszertációját adja közre. Homlokterében a felsőoktatási intézmények, konkrétabban az egyetemek belső irányítási rendszere áll. Nem csupán a fogyatékosságokat és hiányosságokat mutatja be, de a továbbfejlesztés lehetöségeit is feltárja. Alapos történeti visszatekintéssel, valamint nemzetközi kitekintéssel él, elméleti és gyakorlati megközelítést egyaránt alkalmaz. A könyvböl képet kaphatunk a 2000-es évek első felének felsőoktatás-irányítási reformjáról ugyanúgy, ahogy a nyugat- és kelet-közép-európai átalakításokról, valamint azok mozgatórugóiról. (B. A.)

- Közpénzügyek

Kovács Árpád

ELTE Eötvös Kiadó, Budapest, 2010.

Tankönyv. Terjedelem: 379. Bibliográfia a jegyzetekben. 9789633120040.

- A szerző egyetemi oktató, az Állami Számvevőszék volt elnöke, munkája az ELTE Jogi Kari Jegyzetek közé tartozik. Az állam gazdasági szerepének jellemzőivel ismerteti meg a hallgatókat, bemutatja a magyar államháztartási rendszer finanszírozását és működését, a kapcsolódó vagyon hasznosítását és a civil szféra 
szervezeteinek a pénzügyi-gazdasági tevékenységét. Külön fejezet szól a köz- és magánforrásokból, vegyes tulajdoni szerkezetben megvalósított beruházások menedzseléséröl; mindemellett tartalmaz a közpénzügyi rendszerhez kapcsolódó pénzügyi ellenőrzési ismereteket is. A tankönyv végén angol nyelvű összefoglaló található. (Á. Zs.)

- A magyar állam költségvetési joga: Közigazgatási jogi tanulmány MAGYARY Zoltán

Reprint. Országgyűlés Hivatala, Budapest, 2010.

Monográfia. Terjedelem: 224. Bibliográfia a lábjegyzetekben. ISBN nincs.

- Magyary Zoltán (1888-1945) a közigazgatási és pénzügyi jog professzora volt; a kötet az 1923-ban Budapesten megjelentetett mü hasonmás kiadása. A szerzőnek ez idáig elsősorban a közigazgatás-tudományi eredményeit emelték ki, jelen munka bizonysága annak, hogy a költségvetési jog terén is maradandót alkotott. A munka ismerteti a költségvetési jog kialakulásának hazai történetét, elméletét, legfontosabb intézményeit (pl. a költségvetés előkészítését és tárgyalását, az appropriáció intézményét, a költségvetés végrehajtását). A múlt ma is aktualitással bíró közjogi kérdéseit veti fel, és azokra kristálytiszta logikával ad válaszokat. A munkát jogszabályjegyzék, forrás-, valamint betürendes név- és tárgymutató zárja. (B. A.) 